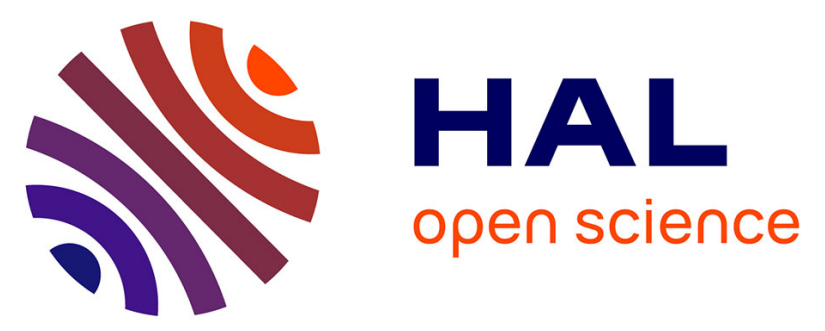

\title{
A new and primitive species of Protophiomys (Rodentia, Hystricognathi) from the late middle Eocene of Djebel el Kébar, Central Tunisia
}

Laurent Marivaux, El Mabrouk Essid, Wissem Marzougui, Hayet Khayati Ammar, Sylvain Adnet, Bernard Marandat, Gilles Merzeraud, Rodolphe Tabuce, Monique Vianey-Liaud

\section{To cite this version:}

Laurent Marivaux, El Mabrouk Essid, Wissem Marzougui, Hayet Khayati Ammar, Sylvain Adnet, et al.. A new and primitive species of Protophiomys (Rodentia, Hystricognathi) from the late middle Eocene of Djebel el Kébar, Central Tunisia. Palaeovertebrata, 2014, 38 (1), pp.e2. 10.18563/pv.38.1.e2 . hal-01813425

\section{HAL Id: hal-01813425 \\ https://hal.umontpellier.fr/hal-01813425}

Submitted on 13 Jun 2018

HAL is a multi-disciplinary open access archive for the deposit and dissemination of scientific research documents, whether they are published or not. The documents may come from teaching and research institutions in France or abroad, or from public or private research centers.
L'archive ouverte pluridisciplinaire HAL, est destinée au dépôt et à la diffusion de documents scientifiques de niveau recherche, publiés ou non, émanant des établissements d'enseignement et de recherche français ou étrangers, des laboratoires publics ou privés. 


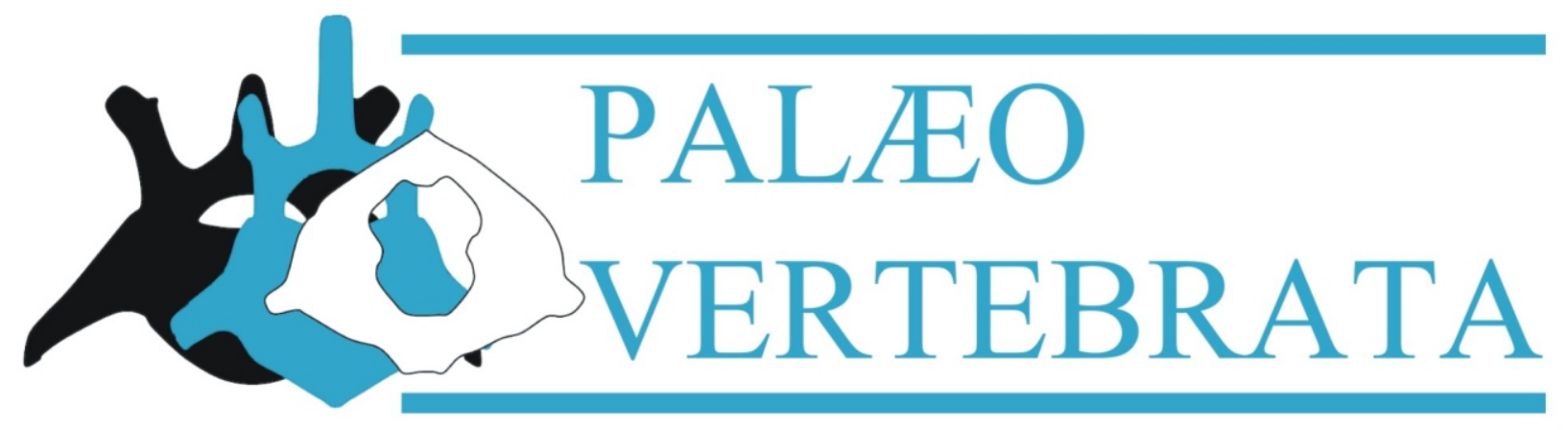

Volume 38 , issue 1 November 2014

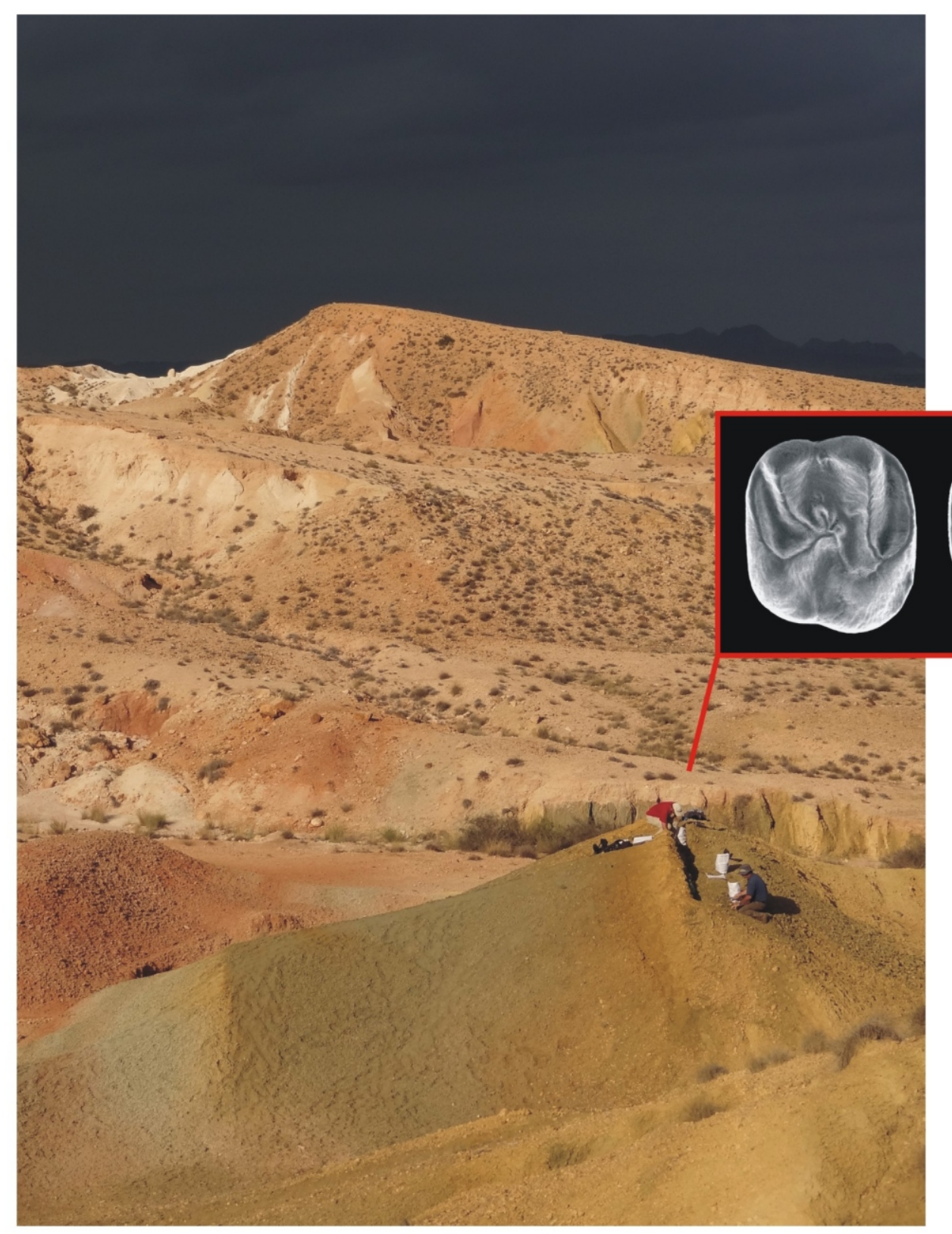

Featured article:

A new and primitive species of Protophiomys (Rodentia, Hystricognathi) from the late middle Eocene of Djebel el Kébar, Central Tunisia 


\title{
A new and primitive species of Protophiomys (Rodentia, Hystricognathi) from the late middle Eocene of Djebel el Kébar, Central Tunisia
}

\section{LAURENT MARIVAUX ${ }^{a *}$, EL MABROUK ESSID ${ }^{\mathrm{b}}$, WISSEM MARZOUGUI ${ }^{\mathrm{b}}$, HAYET KHAYATI AMMAR SYLVAIN ADNET ${ }^{\mathrm{a}}$, BERNARD MARANDAT ${ }^{\mathrm{a}}$, GILLES MERZERAUD ${ }^{\mathrm{c}}$, RODOLPHE TABUCE ${ }^{\mathrm{a}} \boldsymbol{}$ MONIQUE VIANEY-LIAUDa}

\author{
${ }^{a}$ Laboratoire de Paléontologie, Institut des Sciences de l'Évolution de Montpellier (ISE-M, UMR 5554, CNRS, UM2, IRD), c.c. \\ 064, Université Montpellier 2, place Eugène Bataillon, F-34095 Montpellier Cedex 05, France \\ ${ }^{b}$ Office National des Mines (ONM), 24 rue 8601, 2035 La Charguia, Tunis BP: 215 - 1080 Tunis, Tunisia \\ ${ }^{c}$ Géosciences Montpellier (UMR-CNRS 5243), c.c. 060, Université Montpellier 2, Place Eugène Bataillon, F-34095 Montpellier \\ Cedex 05, France \\ * corresponding author: Laurent.Marivaux@univ-montp2.fr
}

\begin{abstract}
Based on fossil discoveries and phylogenetic studies, an Eocene Asian origin for hystricognathous rodents and anthropoid primates has gained strong support in recent years. The two groups then invaded both Africa and South America, which promoted their evolutionary success. However, the fossil record has so far failed to constrain the nature and precise timing of these pivotal dispersal events. In Africa, given the apparent absence of hystricognaths and anthropoids in early to early middle Eocene localities, it is suggested that these mammal groups dispersed from Asia to Africa sometime during the middle Eocene. In this paper, we report the discovery of several isolated teeth of a rodent from a new vertebrate locality situated in central Tunisia (Djebel el Kébar, KEB-1), dating from the late middle Eocene (Bartonian, 39.5 Myr). These fossils document a diminutive new species of Protophiomys (P. tunisiensis nov. sp.), a basal genus of hystricognathous rodents which is well known from several North African mammalian-bearing localities of the end of the Eocene. The teeth of P. tunisiensis display a suite of anatomical details comparable with those observed in the other species of the genus, but with a lesser degree of development. Such an apparent primitive evolutionary stage is corroborated by the greater antiquity of this Tunisian species. P. tunisiensis nov. sp. is so far the most ancient representative of hystricognaths in Africa. However, it can be expected that hystricognaths were already present on that landmass given the new data on early caviomorphs recently reported from South America (at 41 Myr). The arrival of hystricognaths in Africa from South Asia certainly predates the depositional period of the Kébar sediments, but perhaps not by much time.
\end{abstract}

Keywords: North Africa, Bartonian, Dental morphology, Paleobiogeography, Adaptive radiation

Submitted 3 March 2014, Accepted 26 May 2014

(C) Copyright Laurent Marivaux May 2014

\section{INTRODUCTION}

Hystricognaths are a natural group of rodents (infra-order Hystricognathi Tullberg, 1899) that are today represented by the Afro-Asian porcupines, African cane-, mole- and dassie-rats, and the South American guinea pigs, chinchillas, capybaras, pacas, agoutis, etc. From a paleontological perspective, hystricognaths are so far absent (unknown) from the earliest Tertiary fossil record at a global scale. Their earliest occurrences date only from the late middle or early late Eocene in both Africa and South America (Jaeger et al., 1985, 2010a; Sallam et al., 2009; Antoine et al., 2012). Such a record either indicates the existence of a significant Eocene (Lutetian) gap in the hystricognath record, or suggests that this group achieved a rapid widespread distribution in the Old and New Worlds just after its emergence. The record of the earliest hystricognaths was long exclusive to Africa (e.g., Osborn, 1908; Wood, 1968; Jaeger et al., 1985). However, over the past few decades, fossil discoveries in South Asia have demonstrated that this tropical province was also a major centre of an early hystricognathous rodent radiation (the "baluchimyine" radiation), and most likely the ancestral homeland of the Hystricognathi clade (Hussain et al., 1978; Marivaux et al., 2002, 2004; Dawson et al., 2006; Sallam et al., 2009, 2012; Barbière \& Marivaux, in press). From a historical biogeographic perspective, in this context of an Asian origin, it is worth noting that if ancestral Asian hystricognaths dispersed across the Tethys Sea to colonize Africa sometime during the middle Eocene, they were also able to continue their pattern of intercontinental dispersal across the South Atlantic to invade South America as well (e.g., Antoine et al., 2012). Interestingly, the same seems to be true for anthropoid primates (stem Afro-Asian anthropoids and the origin of platyrrhines; e.g., Antoine et al., 2012; Chaimanee et al., 2012; Seiffert, 2012). However, critical factors such as the mode and precise timing of these Asio-African and Afro-South-American dispersals, and the pathways by which these dispersals occurred remain entirely unknown.

In the framework of our paleontological program in the early Tertiary of North Africa, since 2008 we have focused our field research in Tunisia, notably on the geological outcrops exposed in the center of the country (Fig. 1). In the vicinity of the village of Soug-Jedid (Sidi Bouzid Township), the survey of the Eocene shallow marine variegated deposits that are accessible at the foothill of the south-eastern flank of Djebel el Kébar, has allowed for the discovery of a new vertebrate-bearing locality (KEB-1). From this locality, a few isolated teeth of mammals were sorted from several 
hundred teeth of selacians by wet-screening about three tons of sediment during the course of three field seasons. Among these mammalian teeth, one can be attributed to a primate (Marivaux et al., 2014), another to a hyracoid (unpublished material), and several others (more than fifty) to a rodent. In this paper, we analyze the dental material of that rodent. These teeth document a diminutive and primitive new species of Protophiomys, a basal genus of hystricognathous rodents which is well known from Bir el Ater in eastern Algeria (Nementcha mountains: P. algeriensis; Jaeger et al., 1985), Birket Qarun 2

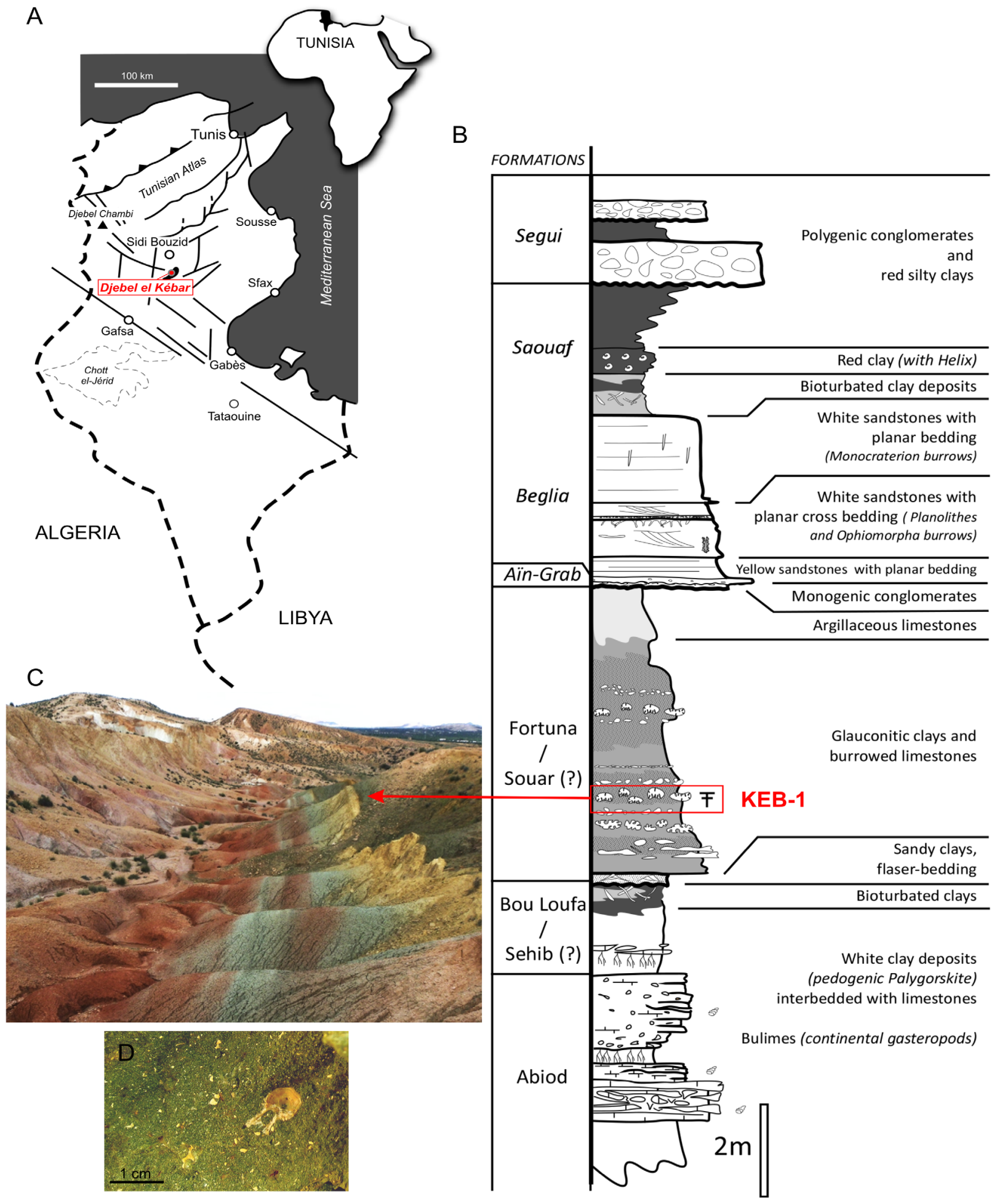

Figure 1. Location map and stratigraphic position of the vertebrate-bearing Djebel el Kébar locus 1 locality (KEB-1) in central Tunisia. A, simplified map of Tunisia showing the location of Djebel el Kébar in central Tunisia (Sidi Bouzid Township, Amamria hamlet - Soug-Jedid village); B, lithostratigraphical log of the Tertiary sedimentological sequence of Djebel el Kébar (south eastern part), indicating the position of the fossiliferous KEB-1 locality (log from Gilles Merzeraud; modified after Merzeraud et al., submitted); C, photograph showing the typical badlands of variegated clays from the early Tertiary sequence of Djebel el Kébar, which corresponds to shallow marine environmental deposits (picture by Gilles Merzeraud). The red arrow indicates the level that has yielded KEB-1; D, photograph of the fossiliferous glauconitic clays of KEB-1 (picture by Monique Vianey-Liaud). 
in Egypt (Fayum BQ-2: P. aegyptensis; Sallam et al., 2009), and possibly from Dur At-Talah in Libya (DT-Loc 1\&2: "P." durattalahensis; Jaeger et al., 2010a; see discussion section), three mammalian-bearing localities very close in age at the end of the Eocene (latest middle [?] to early late Eocene). A few teeth, tentatively referred to Protophiomys (P. cf. algeriensis), were also reported from Sperrgebiet (Silica South and Silica North) in Namibia, two localities that are considered to be Lutetian in age (Pickford et al., 2008; but see discussions about the age of these localities by Marivaux et al., 2012, Coster et al., 2012a, and this paper).

At KEB-1 in Tunisia (Fig. 1), the sediment consists of glauconitic clays, which were formed locally in lagoonal conditions (see Merzeraud et al., submitted). Radiometric $\mathrm{K}-\mathrm{Ar}$ analyses performed on few grains of glauconite extracted from the glauconitic clays embedding the fossils, indicate that KEB-1 is late middle Eocene in age (Bartonian; datings ranging from $38.7 \pm 1.0 \mathrm{Ma}$ to $40.7 \pm 1.1 \mathrm{Ma}$; see Yans in Marivaux et al., 2014). This new species of Protophiomys from KEB-1 (P. tunisiensis sp. nov.) is therefore among the most ancient representatives of the hystricognathous rodents to be recorded in Africa thus far. Here, we describe and compare these new fossils from Tunisia, and discuss the affinities of this new rodent species, with a special emphasis on possible paleobiogeographic and macroevolutionary implications. The dental terminology (Fig. 2) follows that of Marivaux et al. (2004) (modified after Wood \& Wilson, 1936).

\section{SYSTEMATIC PALEONTOLOGY}

Class MAMMALIA Linnaeus, 1758

Order RODENTIA Bowdich, 1821

Suborder CTENOHYSTRICA Huchon, Catzeflis \& Douzery, 2000

Infraorder HYSTRICOGNATHI Tullberg, 1899

Protophiomys Jaeger, Denys \& Coiffait, 1985

(Fig. 3)

Type species. Protophiomys algeriensis Jaeger et al., 1985.

Included species. Protophiomys aegyptensis Sallam et al., 2009; Protophiomys tunisiensis nov. sp.; "Protophiomys" durattalahensis Jaeger et al., 2010, should be referred to another genus sensu Antoine et al. (2012), Sallam et al. (2012) and Barbière \& Marivaux (in press), but see Coster et al. (2012b); Waslamys attiai Sallam et al., 2009, should be reassigned to the genus Protophiomys sensu Coster et al. (2012b).

Range and distribution. Late middle Eocene (Bartonian) of Tunisia to early late Eocene (early Priabonian) of eastern Algeria and northern Egypt (and possibly Lutetian of Namibia; Pickford et al., 2008 [but see discussion in this paper]).

Emended diagnosis. Brachydont upper and lower cheek teeth with low but well-defined cusps (-ids) and lophs (-ids); upper molars without protoconule but with a small to indistinct central metaconule; metaloph joining the vestigial metaconule and never connecting to the posteroloph; mesolophule non-existent or variably developed (weakly to moderately developed); complete mure absent; complete neo-endoloph-enterocrest complex present on M3, variably developed (complete or incomplete) on M2 (hypoflexus partially or entirely closed lingually), but absent on M1 (hypoflexus open lingually); buccal and lingual walls of upper molars and lower molars, respectively, absent to strongly developed; lower molars with complete or subcomplete ectolophid without well-defined mesoconid (vestigial or absent); posterior arm of the protoconid very short (incomplete metalophulid II, buccally limited); anterior cingulid either very weak or absent.

\section{Upper tooth}

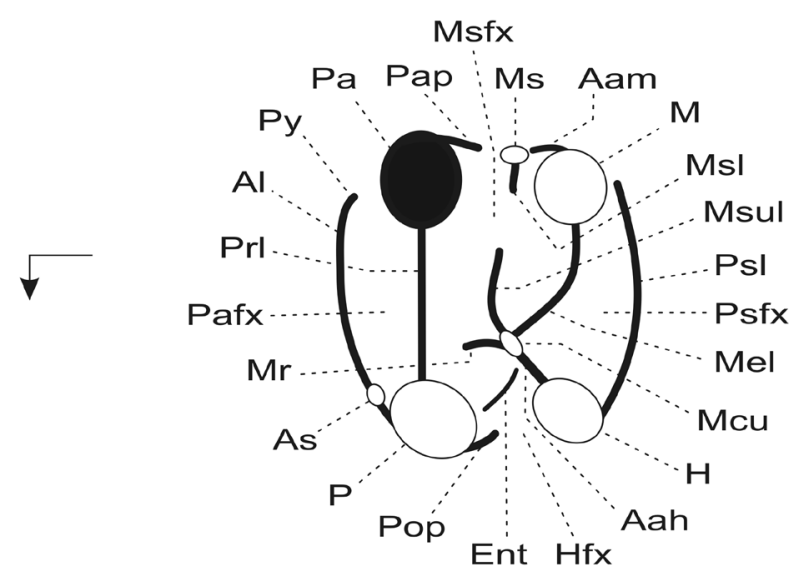

Lower tooth

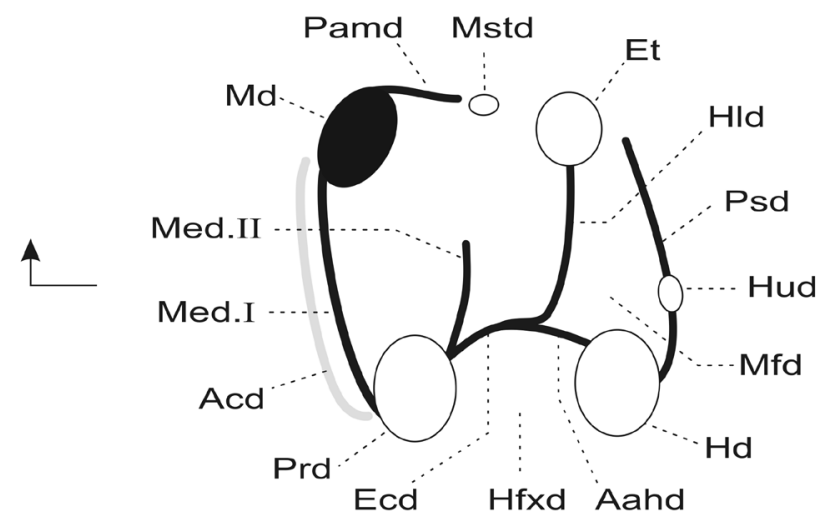

Figure 2. Dental terminology used in the description of the basal hystricognathous rodents. The nomenclature is modified after Marivaux et al. (2004) (modified after Wood \& Wilson, 1936). Arrows indicate mesial (to the left) and lingual sides (pointing arrow).

Upper tooth abbreviations: Aah, anterior arm of the hypocone; Aam, anterior arm of the metacone; Al, anteroloph; As, anterostyle; Ent, enterocrest; H, hypocone; Hfx, hypoflexus (= internal sinus); M, metacone; Mcu, metaconule; Mel, metaloph; Mr, mure; Ms, mesostyle; Msfx, mesoflexus; Msl, mesoloph; Msul, mesolophule; P, protocone; Pa, paracone; Pafx, paraflexus; Pap, posterior arm of the paracone; Pop, posterior outgrowth of the protocone (= neo-endoloph); Prl, protoloph; Psfx, posteroflexus; Psl, posteroloph; Py, parastyle.

Lower tooth abbreviations: Aahd, anterior arm of the hypoconid; Acd, anterocingulid; Ecd, ectolophid; Et, entoconid; Hud, hypoconulid; Hd, hypoconid; Hfxd, hypoflexid (= external sinusid); Hld, hypolophid; Md; metaconid; Med. I, metalophulid I; Med. II, posterior arm of the protoconid (if long and connected to the lingual margin or to the metaconid $=$ metalophulid II); Mfd, metaflexid; Mstd, mesostylid; Pamd, posterior arm of the metaconid; Prd, protoconid; Psd, posterolophid. 
Protophiomys tunisiensis nov. sp.

urn:1sid:zoobank.org:pub:8D979CB2-625F-41D7-80E5-ADE338BE5DE2

Holotype. KEB-1-014, an upper right M2 (Fig. 3M).

Hypodigm. 1 right dp4 (KEB-1-006), 1 left p4 (KEB-1-002), 3 right p4 (KEB-1-033-035), 6 left m1 (KEB-1-003, 036-40), 4 right $\mathrm{m} 1$ (KEB-1-029-032), 8 left $\mathrm{m} 2$ (KEB-1-004, 041-046, 067), 7 right $\mathrm{m} 2$ (KEB-1-023-28, 069), 3 left m3 (KEB-1-005, 047-048), 6 right $\mathrm{m} 3$ (KEB-1-017-022), 1 left DP4 (KEB1-058), 1 right DP4 (KEB-1-073), 1 right $\mathrm{P} 4$ (KEB-1-007), 7 left M1 (KEB-1-007, 010-011, 059-061, 074), 8 right M1 (KEB-1-009, 054-057, 070-072), 5 left M2 (KEB-1-012, 015, 062-063, 075), 4 right M2 (KEB-1-013, 050-052), 4 left M3 (KEB-1-016, 064-066), 2 right M3 (KEB-1-048-049). Dental measurements are reported in Table 1. All these fossils are housed in the paleontological collections of the museum of the "Office National des Mines" of Tunis, Tunisia.

Type locality. Kébar 1 (KEB-1), southern flank of Djebel el Kébar, Amamria hamlet, Soug-Jedid village (Sidi Bouzid region), central Tunisia (Fig. 1).

Age. Late middle Eocene (Bartonian). Dated at $\sim 39.5$ Ma by radiometric $\mathrm{K}-\mathrm{Ar}$ analyses performed on grains of glauconite extracted from the glauconitic clays embedding the fossils of KEB-1 (see Yans in Marivaux et al., 2014).

Etymology. Refers to the provenance of this species (i.e., Tunisia).

Diagnosis. Tiny species, about half the dental size of $P$. algeriensis or P. aegyptensis. Differs from these latter in having a dental pattern characterized by low and thin transverse crests (-ids), tetralophodont (absence of mesolophule) and less quadrangular (more oval in shape) upper molars, anteroloph and posteroloph lower and shorter buccally and not connected to the paracone and metacone, respectively (paraflexus and posteroflexus open buccally), a trigon basin open buccally (no

Table 1. Dental measurements (in mm) of Protophiomys tunisiensis nov. sp. (L, maximum mesiodistal length; $\mathbf{W}$, maximum buccolingual width; $\mathbf{n}$, total number of specimens (n', number of specimens measured [unbroken]); x, mean; SD, standard deviation; OR, observed range).

\begin{tabular}{lccccc}
\hline Tooth & n (n') & & $\mathbf{x}$ & SD & OR \\
\hline dp4 & $1(1)$ & L & 1.42 & - & - \\
& & W & 1.02 & - & - \\
p4 & $4(3)$ & L & 1.29 & 0.08 & $1.21-1.37$ \\
& & W & 1.11 & 0.11 & $0.99-1.22$ \\
m1 & $10(8)$ & L & 1.63 & 0.06 & $1.56-1.69$ \\
& & W & 1.39 & 0.06 & $1.32-1.48$ \\
m2 & $15(13)$ & L & 1.72 & 0.07 & $1.61-1.86$ \\
& & W & 1.53 & 0.08 & $1.43-1.70$ \\
m3 & $9(7)$ & L & 1.72 & 0.14 & $1.50-1.89$ \\
& & W & 1.44 & 0.15 & $1.29-1.74$ \\
DP4 & $2(2)$ & L & 1.27 & 0.05 & $1.24-1.31$ \\
& & W & 1.32 & 0.05 & $1.28-1.36$ \\
P4 & $1(1)$ & L & 1.42 & - & - \\
& & W & 1.55 & - & - \\
M1 & $15(12)$ & L & 1.50 & 0.06 & $1.39-1.54$ \\
& & W & 1.52 & 0.07 & $1.42-1.62$ \\
M2 & $10(9)$ & L & 1.56 & 0.09 & $1.41-1.72$ \\
& & W & 1.75 & 0.13 & $1.57-1.96$ \\
M3 & $6(4)$ & L & 1.57 & 0.08 & $1.44-1.64$ \\
& & W & 1.50 & 0.11 & $1.35-1.60$ \\
\hline
\end{tabular}

buccal wall, mesoflexus open) with a well-defined and individualized mesostyle, a trigonid basin open lingually (absence of elevated lingual wall), the absence of neo-endoloph on M2, and by the presence (sometimes) on M1-2 of a very low, incipient enterocrest (hypoflexus always open lingually even with that crest).

Nomenclatural remark. This new species must be referred to as Protophiomys tunisiensis Marivaux 2014, following the article 50.1 and the "recommendation 50A concerning multiple authors" of the International Code of Zoological Nomenclature (ICZN, 1999: 52, 182).

\section{Description}

Although fragmentary, the dental material documenting this new rodent species is abundant enough to reconstruct complete but composite upper and lower tooth rows.

Deciduous lower premolar. Only one dp4 was discovered at KEB-1. This tooth is noticeably longer than wide, and mesiodistally asymmetric in occlusal outline due to its trigonid, which is pinched buccolingually with respect to the talonid (Fig. 3E). The protoconid and metaconid are equal in size, buccolingually well separated, and slightly more elevated than the talonid cuspids. There is neither metalophulid I nor metalophulid II. Mesially, the tooth bears a small but distinct and cuspidate anteroconid. This mesial cuspid is linked to the metaconid by a short but high anterior cingulid. This cingulid is developed lingually but not buccally, and the trigonid basin remains open buccally as a result. On the talonid, the entoconid and hypoconid are buccolingually opposed and linked by a thin, low (somewhat faintly visible) and straight hypolophid. The anterior arm of the hypoconid is moderately long and connects both the hypolophid and a mesiodistally elongate ectolophid. This latter longitudinal cristid is thin, straight and complete, being connected to the distal flank of the protoconid. There is neither development of a mesoconid nor an incipient mesolophid in the middle of the ectolophid. The entoconid extends mesially via the development of a strong anterior arm. This latter joins the posterior arm of the metaconid, which is also well-marked. These two arms form a lingual wall, which closes the talonid basin lingually. Distally, the crown displays a low posterior cingulid, which bears a strong hypoconulid near the midline. This distal cuspid is virtually as large as the hypoconid, and both cuspids are linked by a trenchant post-hypoconid cristid. The posterior cingulid remains very low between the hypoconid and hypoconulid, but forms a posterolophid between the hypoconulid and entoconid.

Permanent lower premolar. The p4 is clearly shorter than dp4, and it exhibits a much simpler dental pattern (Fig. 3A). This is particularly shown in the absence of an anteroconid and a hypolophid, but also in the absence of development of anterior and posterior cingulids. As on dp4, p4 is also slightly asymmetric in having its talonid broader than the trigonid. The protoconid, metaconid, hypoconid, entoconid and hypoconulid are equal in size, but the mesial cuspids are slightly more elevated. The lingual cuspids are opposed to the buccal cuspids. As dp4, p4 displays a long and complete longitudinal ectolophid without a mesoconid. The protoconid and metaconid appear to be more separated than they are on dp4. Both mesial cuspids are linked by a thin but complete metalophulid II. Distally, the hypoconulid is in a more internal position (more aligned on 
the hypoconid-entoconid axis), and as such it does not form a distinct heel as it does on dp4. Lingually, the talonid remains open due to the absence of development of both the posterior arm of the metaconid and the anterior arm of the entoconid.

Lower molars. The three molars are brachydont, longer than wide, and exhibit very similar cuspid and cristid arrangements (Fig. 3B-D). The first molars (m1; Fig. 3B) are distinguishable by the position of the protoconid, which is slightly more lingual than the hypoconid on a mesiodistal axis (i.e., talonid barely broader than the trigonid). The third molars (m3; Fig. 3D) are also clearly recognizable by the position of the entoconid, which is more buccal with respect to the metaconid along the mesiodistal axis (trigonid barely broader than the talonid). The second molars (m2; Fig. 3C) are in contrast perfectly

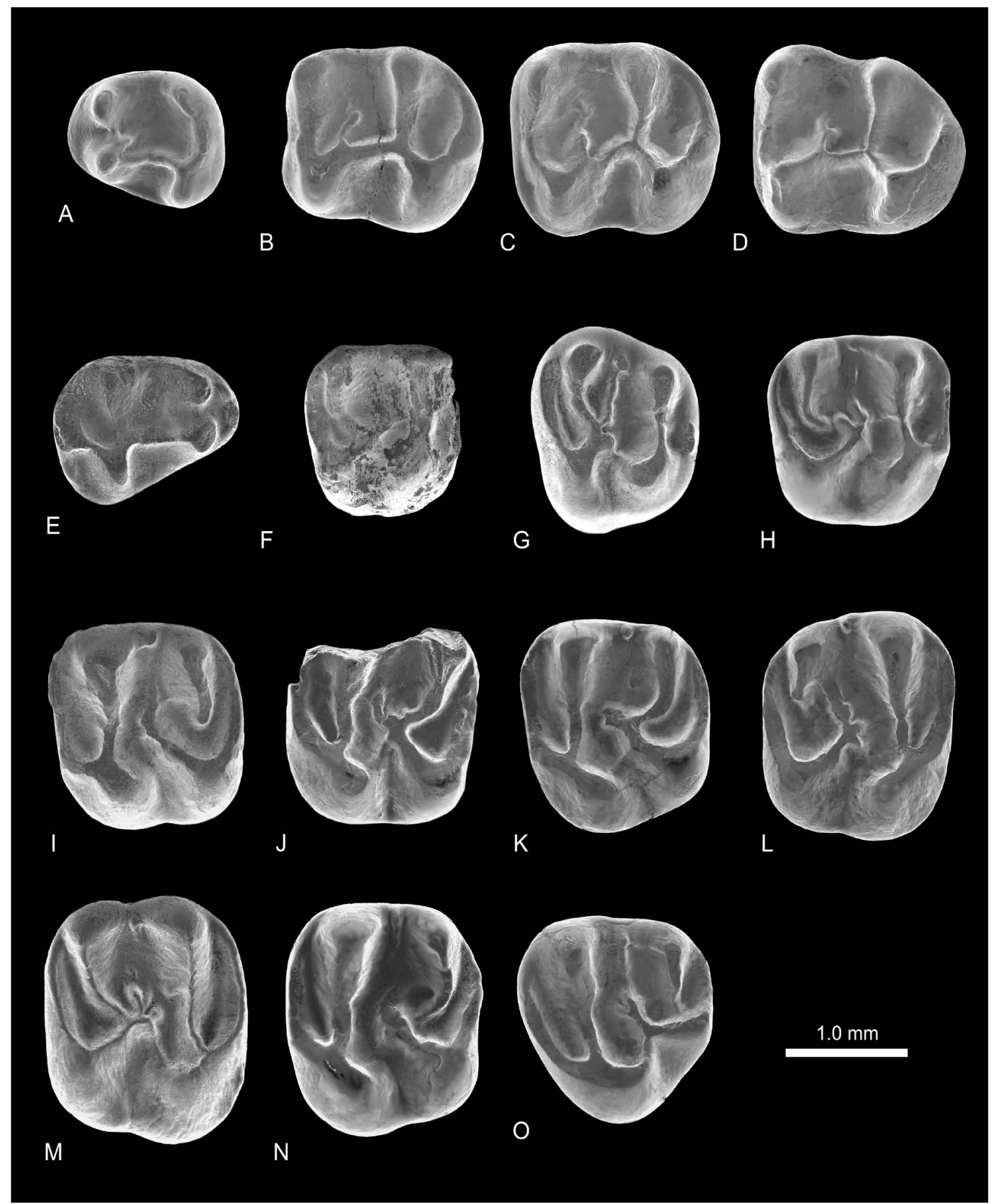

Figure 3. Lower and upper teeth of Protophiomys tunisiensis nov. sp. from the late middle Eocene of Djebel el Kébar locus 1 (KEB-1), central Tunisia (dimensions: length $\mathrm{x}$ width, in mm). A, KEB-1-002, left lower p4 (1.30 x 1.13); B, KEB-1-003, left lower m1 (1.67 x 1.45); C, KEB-1-004, left lower m2 (1.73 x 1.53); D, KEB-1-005, lower left $\mathrm{m} 3$ (1.78 x 1.46); E, KEB-1-006, lower right dp4 (1.42 x 1.02); F, KEB-1-073, right upper DP4 (1.31 x 1.36); G, KEB-1-008, right upper P4 (1.42 x 1.55); H, KEB-1-009, right upper M1 (1.52 x 1.50); I, KEB-1-010, left upper M1 (1.51 x 1.58); J, KEB-1-011, broken left M1 (1.62 x -); K, KEB-1-012, left upper M2 (1.57 x 1.65); L, KEB-1-013, right upper M2 (1.60 x 1.82); M, KEB-1-014, right upper M2 (1.72 x 1.96); N, KEB-1-015, left upper M2 (1.59 x 1.83); O, KEB-1-016, left upper M3 (1.64 x 1.60). 
rectangular, with the distal cuspids mesiodistally opposed to the mesial cuspids. On the three molars (m1-3), the metaconid and entoconid occupy a position slightly more anterior to the protoconid and hypoconid, respectively. These four main cuspids are acute and roughly equal in size. Distally, the hypoconulid is strong, but barely smaller than the other main cuspids. This distal cuspid occupies a position slightly buccal to the midline. On each dental locus, mesiobuccally one can observe the presence of a short and not very extensive anterior cingulid. On some specimens, this anterior cingulid can reach the mesial base of the metaconid, but its development remains subtle. The three molars are tetralophodont and characterized by transverse cristids that are sub-parallel, very thin, and relatively low compared to cusp height. The metalophulid I is complete and forms the mesial margin of the teeth. This mesial transverse cristid is slightly curved in its buccal part due to the small distal displacement of the protoconid. The second transverse cristid is a very short posterior arm of the protoconid, which does not reach the lingual margin (or the metaconid), and therefore does not form a metalophulid II. The third transverse cristid is the hypolophid, which links the entoconid to the junction between the ectolophid and the anterior arm of the hypoconid. This latter is distinct, being long and oblique (directed mesiolingually). The fourth transverse cristid is the posterolophid, which is trenchant, curved and bears the hypoconulid. Lingually, the posterolophid weakens but reaches the distal base of the entoconid. On $\mathrm{m} 3$, the posterolophid exhibits a shorter radius of curvature than that observed on m1-2, due to the buccal displacement of the entoconid (Fig. 3D). The ectolophid is long, oblique and complete, running from the mesial extremity of the anterior arm of the hypoconid to the protoconid. There is neither a mesoconid nor a mesolophid. Lingually, the talonid basin remains open due to very weak development of the posterior arm of the metaconid and the absence of an anterior arm of the entoconid.

Deciduous fourth upper premolar. Two specimens have been identified, but only one provides occlusal details (Fig. 3F). This specimen is, however, slightly worn and broken mesially, and although appearing to be quadrangular (length = breadth), it was probably trapezoidal in occlusal outline (buccal length $>$ lingual length) judging from the surface of breakage mesiobuccally. This tooth is low crowned, tetralophodont, and displays four bulbous main cusps (protocone, paracone, metacone and hypocone), plus a minute cusp (metaconule), which is in nearly a central position on the crown. The transverse crests are low and parallel. The metaconule bears a very short and buccally oriented enamel wrinkle that could correspond to an incipient mesolophule. The anterior crest is not an anteroloph, but a low cingulum that is not connected to the protocone lingually. Mesiobuccally, this anterior cingulum is worn and broken, but it was probably more extensive. The protoloph is rectilinear and links the lingual side of the paracone to the protocone mesiobuccally. The metaloph runs lingually from the metacone but makes a sharp bend at midline toward the metaconule, and it connects to this latter cusp. The anterior arm of the hypocone is short, oblique, and attached mesially to the metaconule. The posteroloph, connected lingually to the hypocone, runs buccally and weakens progressively to end at a point directly distal to the metacone. On the buccal margin, the posterior arm of the paracone and the anterior arm of the metacone can be weakly to moderately developed, but the mesoflexus remains open buccally. Lingually, the protocone does not show any distal outgrowth (i.e., no neo-endoloph), but a small and low enterocrest can be observed. This short crest closes partially the hypoflexus lingually. The metaconule also shows a very short and longitudinal wrinkle (incipient mure) that closes the hypoflexus buccally (no connection between the hypoflexus and mesoflexus).

Permanent fourth upper premolar. This tooth is less low-crowned than DP4, and is sub-oval in occlusal outline, being much broader transversely than it is long (Fig. 3G). However, its dental pattern is basically similar to that of DP4, although differing in the position and development of some cusps and crests. As DP4, P4 displays a well-defined hypocone, which develops a strong and short anterior arm that connects a minute metaconule. The protocone and hypocone are mesiodistally opposed, while the paracone is lingually displaced with respect to the metacone. The anteroloph is very low and very limited buccolingually, being neither connected to the protocone nor to the paracone. The protoloph is straight and trenchant, and links the paracone to the protocone. The metaloph is oblique (mesiolingually oriented), running from the metacone to the metaconule. At the metaconule-metaloph connection, there is a low, thin, but long mesolophule, which runs buccally to reach a minute mesostyle in buccocentral position (located between the paracone and metacone). The posteroloph is also trenchant, running buccally from the hypocone to the distobuccal border of the crown. It connects the distal base of the metacone. Lingually, there is no trace of neo-endoloph (bulbous protocone), but a very low and oblique enterocrest, running between the protocone and metaconule, partially closes the hypoflexus.

Upper molars. Although differing in size and occlusal outline shape, the three upper molars share the same dental structure, which is in fact similar to that of P4 and DP4. M1 (Fig. 3H-J) and M3 (Fig. 3O) are roughly equal in size and smaller than M2 (Fig. 3K-N). M3 differs substantially from M1-2 in having a hypocone strongly displaced buccally, thereby lending a characteristic heart-shaped occlusal outline to the tooth. M3 differs also from M1-2 in having a smaller metacone, a protocone buccolingually compressed, a short but well-defined mesoloph, and in showing the development of a long and high neo-endoloph/ enterocrest complex, which appears hook-like. This long crest complex connects a minute metaconule (faintly distinguishable) situated at the mesial extremity of a long and longitudinal anterior arm of the hypocone, thereby closing the hypoflexus lingually. M1s are quadrangular (length = breadth), while M2s are more rectangular, being much broader transversely than long. M1s and M2s differ also by the position of the hypocone, which is more buccally positioned to the protocone in M2s, while on M1s the hypocone is distally opposed to the protocone. As for the premolars, M1-3 are brachydont and tetralophodont. The main cusps are well-defined from the transverse crests (moderately bunodont). The anteroloph (strongly connected to the protocone) and posteroloph (strongly connected to the hypocone) are both trenchant in their lingual part, but weaken progressively in their buccal part. They end at a point directly mesial and distolingual to the paracone and metacone, respectively. There is neither a parastyle nor a metastyle, and the paraflexus and posteroflexus remain open buccally. On some M1 and M2, the anteroloph bears a small enamel swelling in its most lingual part that could indicate the presence of a minute anterostyle. Buccally, there is a minute and isolated mesostyle, which is situated between the paracone and metacone. There is no buccal wall (absence of posterior arm of the paracone and anterior arm of the metacone) and the mesoflexus is open buccally. The metaloph is generally oriented buccolingually in its buccal part (parallel to the protoloph). At midline, it can 
end abruptly (Fig. 3I, L) or it can bend mesially and sharply toward the metaconule (Fig. 3H, J, K, M, N). In this latter case, the metaloph can either reach the metaconule, or not. Some specimens display an enamel wrinkle emerging from the metaconule (Fig. 3H, I, J, M). This wrinkle is directed buccally, but remains short, thin, and low (highly variable), and it might indicate the presence of an incipient mesolophule. One M2 (KEB-1-013; Fig. 3L) exhibits a longer but low mesolophule, this latter being buccodistally oriented (toward the metacone).
This tooth shows also a very short metaloph (limited in its buccal part). Unlike M3, the protocone of M2 and M1 are not clearly buccolingually compressed. On these two dental loci, the protocone remains well-defined (rounded) and there is no development of neo-endoloph. The hypoflexus is always transversely open. On some teeth (most often M2), the presence of a very low and oblique enterocrest can be observed, running between the protocone and metaconule.

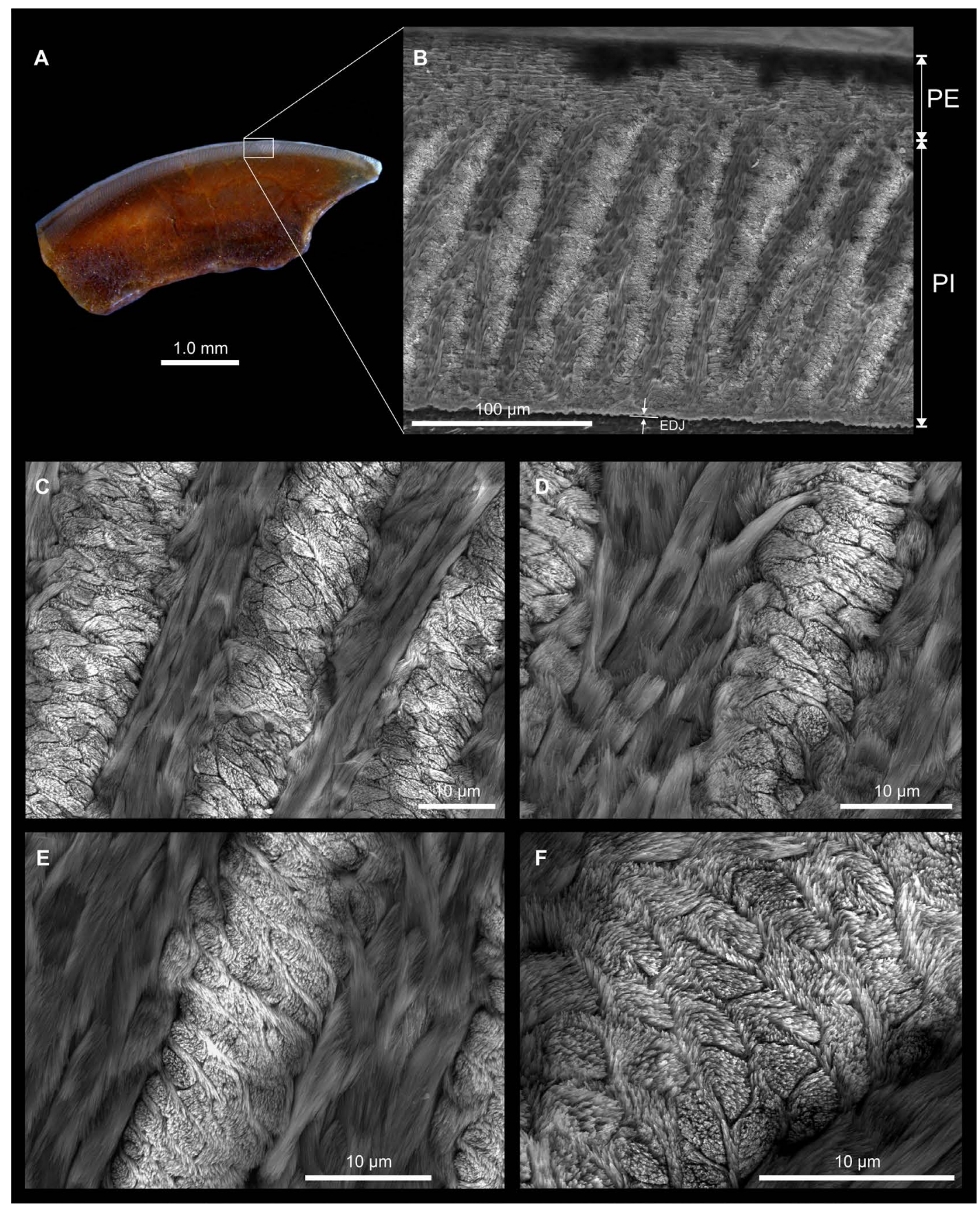

Figure 4. Optical and scanning electron photomicrographs of KEB-1-053, an upper incisor for which the enamel microstructure is detailed at different magnification. $\mathbf{A}$, longitudinal section of the incisor showing the enamel layer on the top of the tooth (optical photograph); $\mathbf{B}$, studied area: the portio externa (PE) represents $23 \%$ of the total enamel thickness and displays radial enamel, the portio interna (PI) displays multiserial Hunter-Schreger bands (HSBs), which are inclined at $70-80^{\circ}$ to the enamel-dentine junction (EDJ); C, microstructural detail of 'B' showing five decussating HSB with three (often four) prisms per band, and the inter-prismatic matrix (IPM) anastomosing regularly between prisms, and with its crystallites running nearly parallel or at a low angle to the prism direction; $\mathbf{D}$, microstructural detail of ' $\mathrm{B}$ ' showing two HSBs with three prisms and similar IPM arrangement than ' $\mathrm{C}$ '; $\mathbf{E}$, microstructural detail of ' $\mathrm{B}$ ' showing three HSBs but more particularly the IPM, which anastomoses regularly between prisms; F, microstructural detail of 'B' showing one HSB, notably the prism shape in section, which is suboval. The pattern of the IPM arrangement typifies a primitive multiserial condition designated as multiserial subtype I (see Martin, 1994). 
Incisor Enamel Microstructure. Among the dental material collected from wet-screening of the KEB-1 sediment are a few fragments of rodent incisors. Although incomplete, the size of these incisors is compatible with that of the molars of Protophiomys tunisiensis, thereby suggesting that these incisors could tentatively be referred to this taxon (the sole rodent recorded at KEB-1). One fragment of upper incisor (KEB-1-053) was embedded in artificial resin and subsequently polished longitudinally (Fig. 4A). The polished section was then etched for $30 \mathrm{sec}$ with $\mathrm{H}_{3} \mathrm{PO}_{4}(37 \%)$ to make the microstructural details visible (Fig. 4B-F).

In longitudinal section (Fig. 4B), the total enamel thickness is about $0.21 \mathrm{~mm}$ and is formed by two distinct layers: the portio interna (PI) and the portio externa (PE). The PE has radial enamel and represents about $23 \%$ of the total enamel thickness. The PI is very thick (\# $0.16 \mathrm{~mm}$ ) and consists of decussating layers of prisms, which are Hunter-Schreger bands (HSBs). There are generally 3-4 prisms wide per band (Fig. 4C-F). The prisms are slightly flattened, thereby appearing suboval in cross section (Fig. 4E-F). The HSBs are inclined at $70-80^{\circ}$ to the enamel-dentine junction (EDJ). The inter-prismatic matrix (IPM) in the PI is thin and never surrounds the prisms. The IPM crystallites run nearly parallel or at a very low angle to the prism direction, and they anastomose regularly between the prisms (Fig. 4D-F). There is no transition zone between adjacent decussating HSBs. Such a crystallite arrangement in PI determines a multiserial enamel (Korvenkontio, 1934). The pattern of the IPM arrangement typifies a primitive multiserial condition, which is recognized as multiserial subtype I (see Martin, 1994). This enamel microstructure is therefore slightly less advanced (more primitive) than that observed in the incisor analyzed from Bir el Ater (Algeria; Martin, 1993), which show an IPM arrangement typifying a multiserial subtype II (acute angular and anastomosing IPM). This incisor from Bir el Ater is probably referable to Protophiomys algeriensis (Table 2; Jaeger et al., 1985). Regrettably, the incisor enamel microstructure has not been investigated in hystricognaths from Dur At-Talah (DT-Loc 1\&2) and Fayum Birket Qarun 2 (BQ-2) localities, thereby restricting the scope of comparisons that can be made with the other known species of Protophiomys, but also other species of close genera.

\section{Comparisons}

Remark. We provide in Table 2 a list of early Afro-Asian hystricognathous rodents with information regarding their geographical provenance, age, and references.

Dental comparisons. Among the different species attributed to the genus Protophiomys (P. algeriensis, P. aegyptensis, " $P$." durattalahensis; Figs 5-6), P. tunisiensis nov. sp. is relatively smaller in size (roughly similar in size to " $P$." durattalahensis) and slender in overall morphology. Compared with the other species, $P$. tunisiensis displays a dental pattern that is characterized by low and thin transverse crests (-ids) and by well-defined and salient cusps and cuspids (Fig. 5A-B). Unlike $P$. algeriensis, $P$. aegyptensis and " $P$." durattalahensis, the trigon basin of upper molars of $P$. tunisiensis is open buccally. This is due to the lack of strong development of the posterior arm of the paracone and the anterior arm of the metacone (lack of buccal wall) as is observed in the other species. There is only a minute, low and isolated mesostyle between the paracone and metacone, which slightly obstructs the mesoflexus buccally. In the other species of the genus, a mesostyle is also distin- guishable (somewhat larger), but it is entirely included in the buccal wall. Upper molars (notably M1-2) of P. tunisiensis do not exhibit a mesiodistal pinch of the protocone associated with the development of a distal outgrowth (i.e., neo-endoloph) as it is observed in all other species of the genus (Fig. 5C, E), but also in the Protophiomys-like taxa such as Waslamys (W. attiai; Fig. 6C) or Baluchimys (B. krabiense, B. barryi), and in more recent hystricognath taxa (Table 2) such as Phiomys (Ph. hammudai, Ph. andrewsi), Acritophiomys (A. bowni), Metaphiomys (M. schaubi), Hodsahibia (H. azrae, $H$. beamshaiensis, H. gracilis), Bugtimys (B. zafarullahi), or Lophibaluchia (L. pilbeami). This simple and primitive structure of the protocone is observed in bunodont taxa of the group such as Talahphiomys (T. lavocati, T. libycus; Fig. 6E) and Lindsaya (L. derabugtiensis) (Table 2). However, $P$. tunisiensis differs substantially from these two latter genera in having a more crested dental pattern with less inflated cusps and cuspids, and in having a metaconule on upper molars, which is virtually undistinguishable (vestigial) compared to the prominent metaconule present in Talahphiomys and Lindsaya. The condition of the metaconule in P. tunisiensis differs also from the condition observed in upper molars of some Asian hystricognaths (such as Ottomania, Bugtimys and Hodsahibia), in which this central cusps is still distinct.

On the upper molars, $P$. tunisiensis also differs from $P$. algeriensis and $P$. aegyptensis in lacking the strong development of the oblique enterocrest (notably on M2). In $P$. tunisiensis, this crest is variably developed and can be absent (Fig. 3). When it is present, it remains very low and it never closes the hypoflexus lingually as it does on M2 of $P$. algeriensis and $P$. aegyptensis (Fig. 5C, E). It is noteworthy that the enterocrest is absent on M1-2 of "P." durattalahensis, and as such the hypoflexus remains always open lingually in this species despite the strong and long development of the neo-endoloph (Fig. 6A).

As in $P$. algeriensis and $P$. aegyptensis, upper molars of $P$. tunisiensis are primarily tetralophodont, a condition which is described by the presence of an anteroloph, a protoloph, a metaloph and a posteroloph (Fig. 5A, C, E). However, some upper molars of these three species can bear a short and buccally oriented enamel wrinkle that is attached to the vestigial metaconule. This short crest could represent an incipient mesolophule. The presence of this character is rare on upper molars of $P$. tunisiensis and $P$. aegyptensis but it is more frequent on molars of $P$. algeriensis. In contrast, this character is constant and well-developed (long mesolophule reaching the buccal margin [mesostyle]) in "P." durattalahensis (Fig. 6A) but also in Waslamys attiai (Fig. 6C), a condition that completes the derived pentalophodont pattern in these two latter species. The pentalophodonty of upper molars, characterized by a strong development of that central transverse crest (i.e., mesolophule), is common in several more advanced Afro-Asian hystricognathous taxa (e.g., Acritophiomys, Phiomys, Metaphiomys, Turkanamys, Lophibaluchia, Hodsahibia, Bugtimys...), but also in the earliest known South American hystricognaths (Cachiyacui, Canaanimys; Antoine et al., 2012). Interestingly, one upper molar identified as an M2 (KEB-1-013; Fig. 3L) of $P$. tunisiensis, exhibits an unusual tetralophodont pattern compared to the other upper teeth referred to this species. This tooth has a very short metaloph (virtually non-existent, limited in its buccal part) but in contrast displays a long mesolophule, which is oblique (buccodistally oriented). This tooth is likely a variant of the other upper molars. However, in developing such an arrangement of the metaloph-mesolophule, the dental 

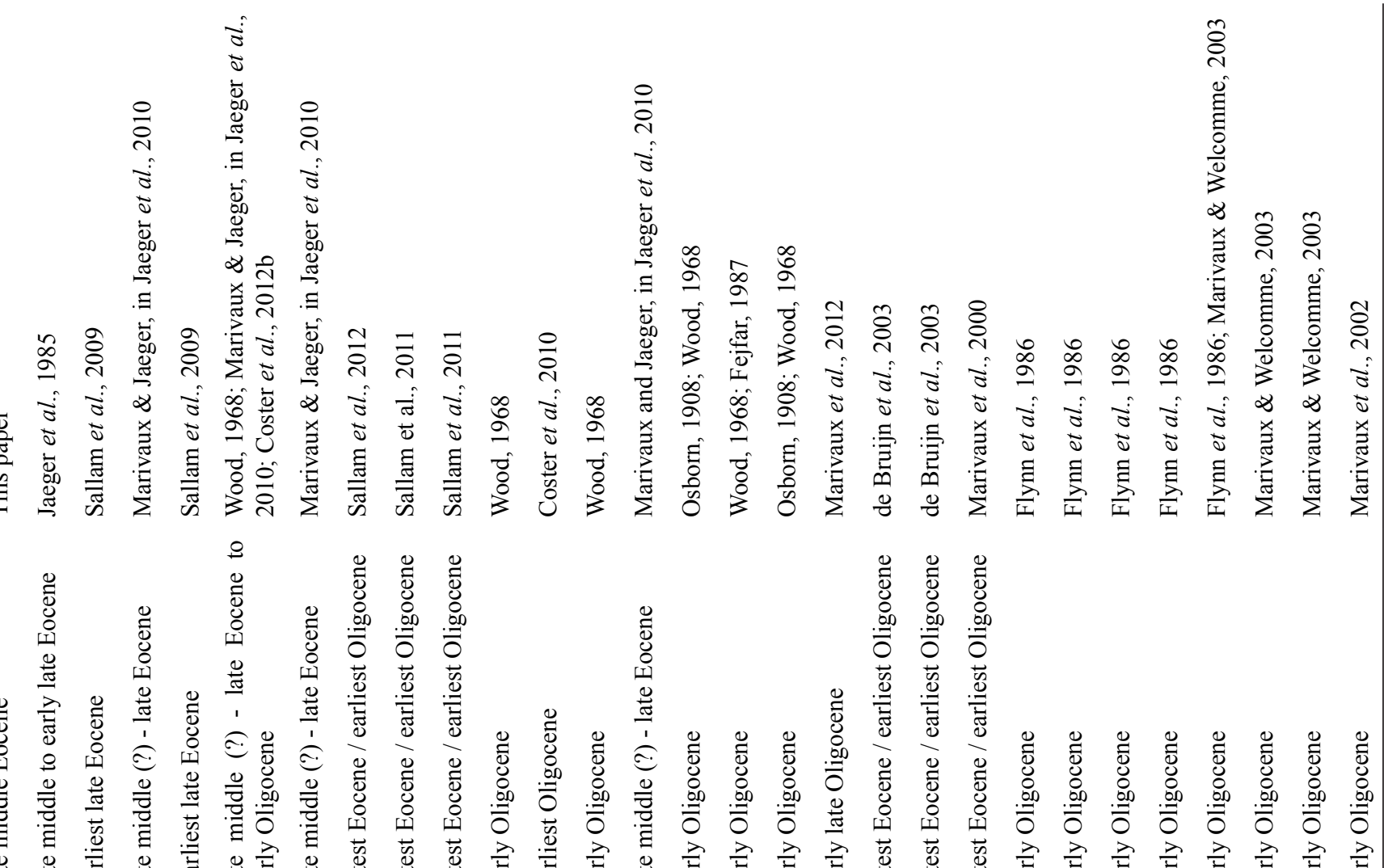

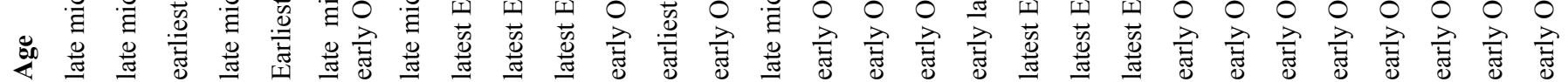

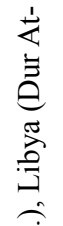

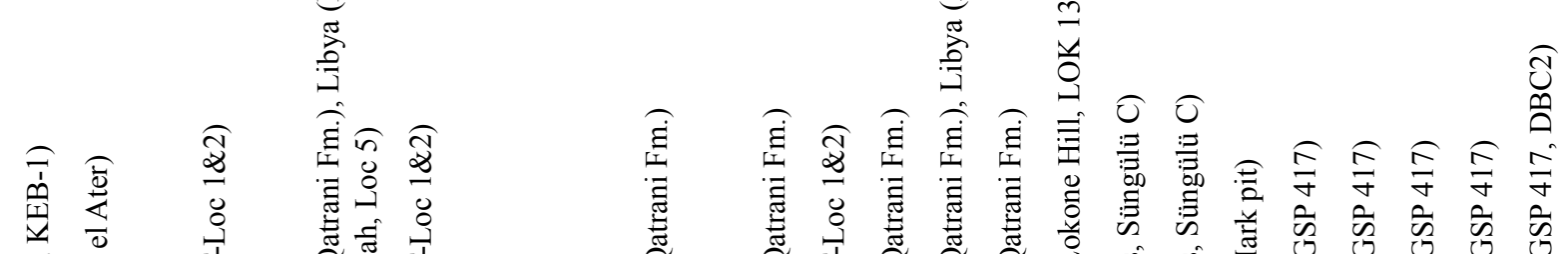

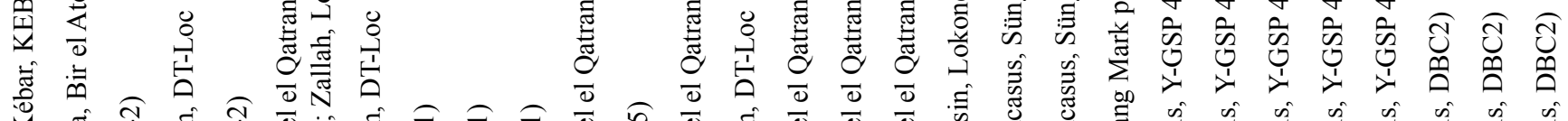

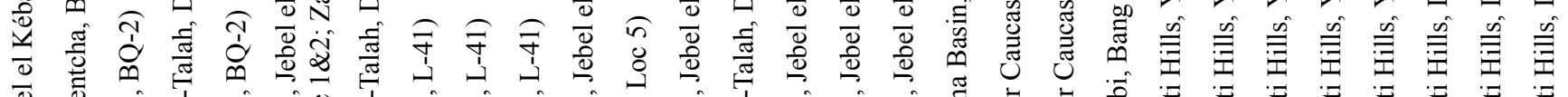

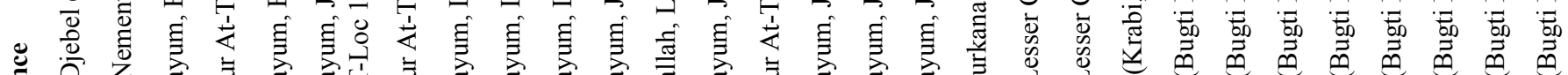
氙 总
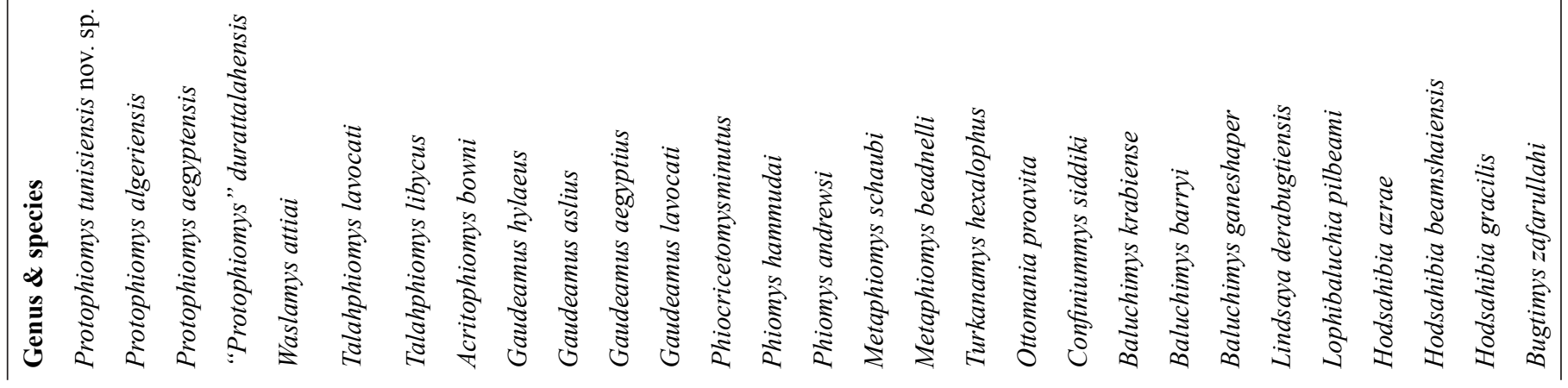

Table 2. List of most of the early hystricognathous rodents from the Paleogene of Africa, South Asia, Asia Minor, and South America that are mentioned in the comparison section. 
pattern of this tooth, although less bunodont, is somewhat reminiscent of that on the M2 of Talahphiomys libycus (Jaeger et al., 2010a: 203, fig. 5u).

The P4 attributed to P. tunisiensis (KEB-1-007; Fig. 3G) exhibits a long but very low central transverse crest, which runs from the mesial extremity of the anterior arm of the hypocone to a minute and buccal mesostyle. The presence of a mesolophule is not observed on P4 of the other species of the genus. Additionally, the anteroloph of KEB-1-007 is not developed and not connected to the protocone, and in fact, it appears as a low cingulum buccolingually limited. This condition differs from that observed on $\mathrm{P} 4 \mathrm{~s}$ of $P$. algeriensis, $P$. aegyptensis or " $P$." durattalahensis, in which the anterior cingulum is longer and more elevated, thereby forming a functional and trenchant
A

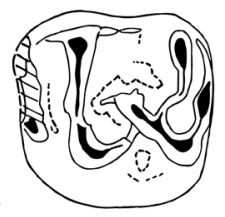

B

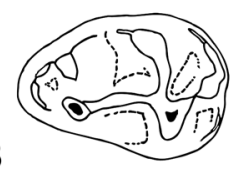

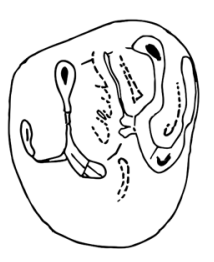
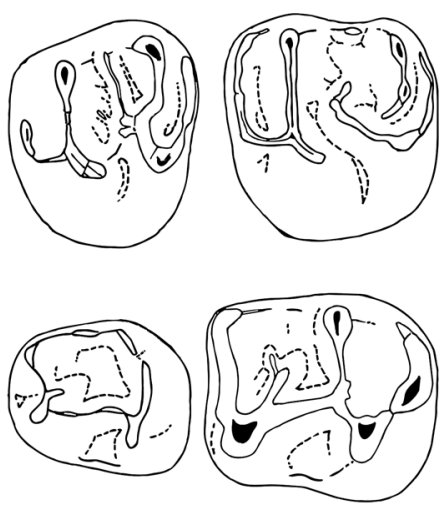
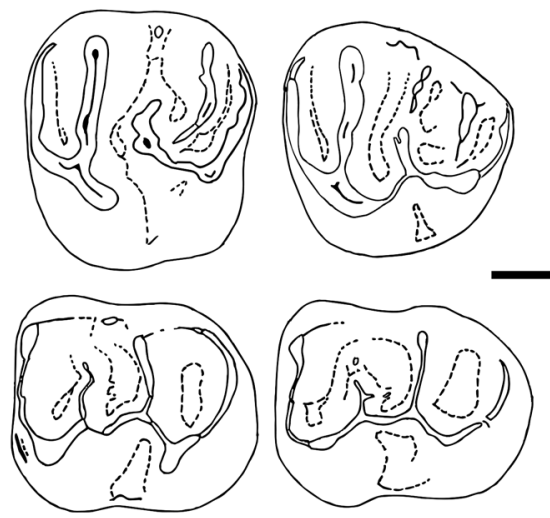
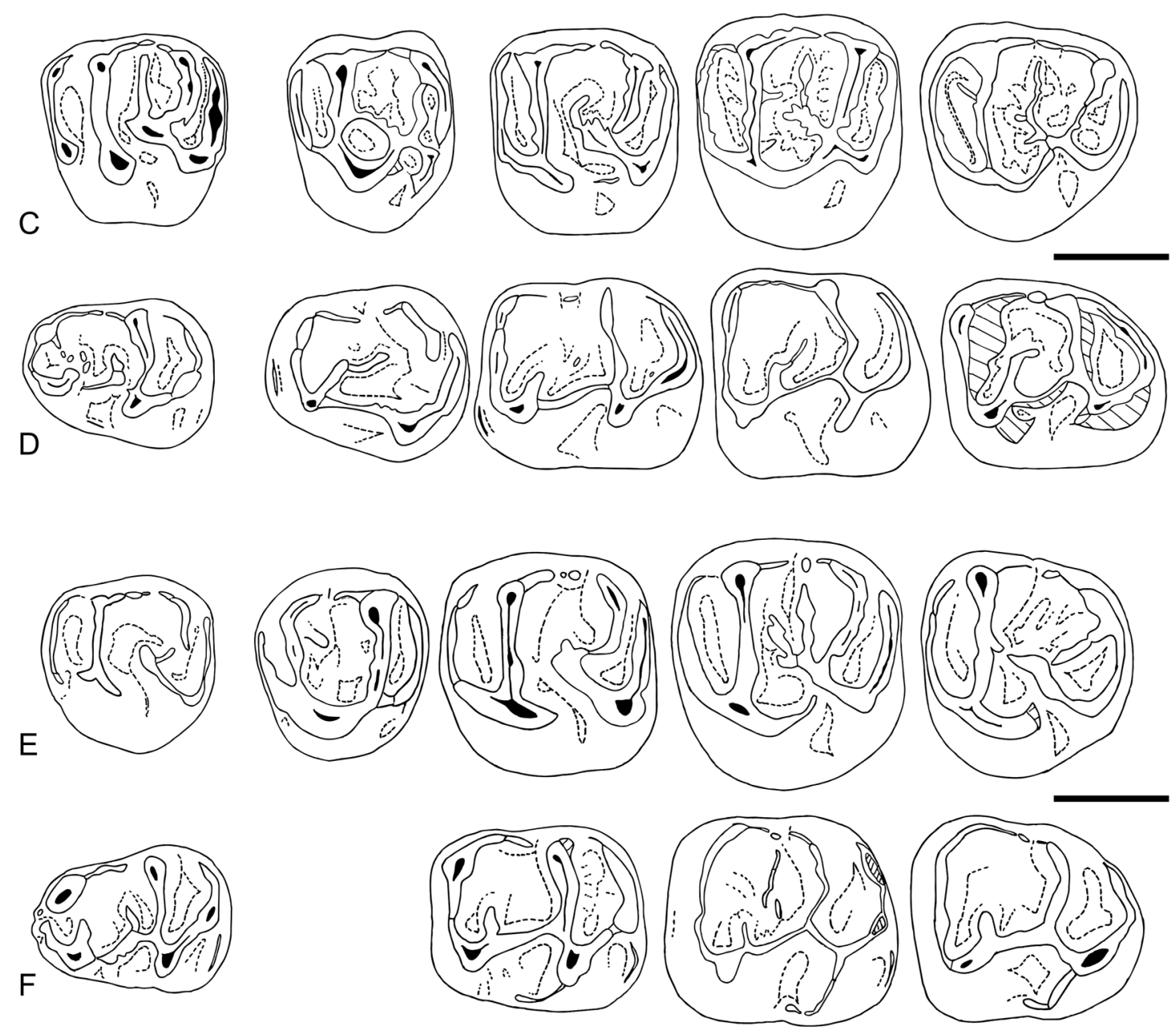

Figure 5. Schematic line drawings of composite upper and lower dentitions of early stem hystricognaths from Africa. A-B, Protophiomys tunisiensis nov. sp.: DP4 and P4, M1-3 (A), dp4 and p4, m1-3 (B); C-D, Protophiomys algeriensis Jaeger et al., 1985: DP4 and P4, M1-3 (C), dp4 and p4, m1-3 (D); E-F, Protophiomys aegyptensis Sallam et al., 2009: DP4 and P4, M1-3 (E), dp4 and m1-3 (F). Some isolated right teeth are reversed to be included in the composite left tooth rows. Scale bars: $1 \mathrm{~mm}$. Drawings by Monique Vianey-Liaud. 
anteroloph. Finally, KEB-1-007 differs also from its counterparts in the other species of the genus in showing a well-defined and cuspate hypocone as well as a stronger and longer anterior arm of that hypocone, which delimits (with the protocone) a shallow internal sinus.

As in P. algeriensis, P. aegyptensis and " $P$." durattalahensis, the anteroloph and posteroloph on the upper molars of $P$. tunisiensis are both trenchant in their lingual part, but in $P$. tunisiensis they weaken progressively in their buccal part. These two lophs also expand less buccally (buccolingually shorter) than in molars of the other species. Indeed, the anteroloph and posteroloph end at a point directly mesial and distolingual to the paracone and metacone, respectively. This arrangement of these two lophs make the crown more ovoid in occlusal outline, a condition which clearly differs from the more quadrangular occlusal outline characterizing upper teeth of the other species of the genus (Figs 5A, C, E and 6A). In $P$. tunisiensis, there is neither a parastyle nor a metastyle, the anteroloph and posteroloph end buccally close to the base of the paracone and metacone, respectively (not connected to them), and the paraflexus and posteroflexus remain open buccally as a result.
A

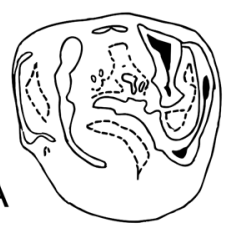

B

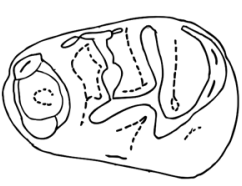

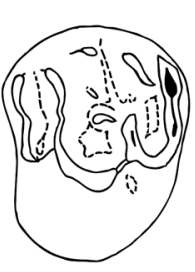
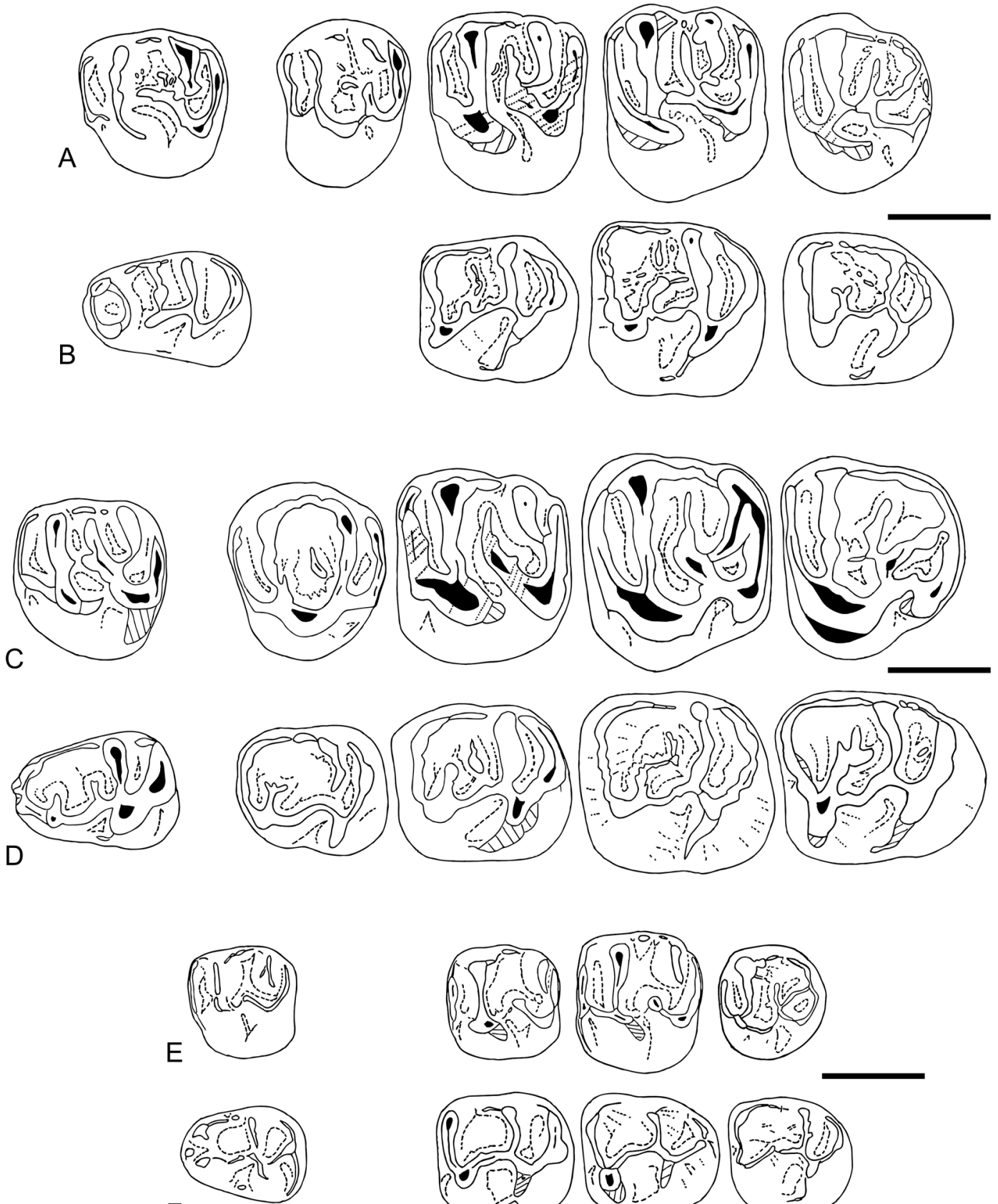

F
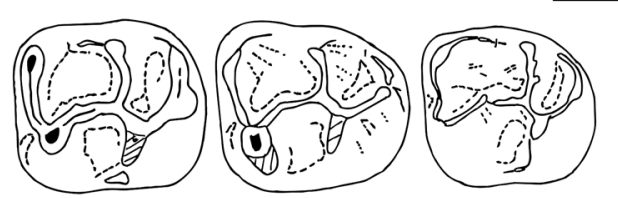

Figure 6. Schematic line drawings of composite upper and lower left dentitions of early stem hystricognaths from Africa. A-B, "Protophiomys" durattalahensis Jaeger et al., 2010: DP4 and P4, M1-3 (A), dp4 and m1-3 (B); C-D, Waslamys attiai Sallam et al., 2009: DP4 and P4, M1-3 (C), dp4 and p4, m1-3 (D); E-F, Talahphiomys lavocati Jaeger et al., 2010: DP4 and M1-3 (E), dp4 and m1-3 (F). Some isolated right teeth are reversed to be included in the composite left tooth rows. Scale bars: $1 \mathrm{~mm}$. Drawings by Monique Vianey-Liaud. 
As in $P$. algeriensis and $P$. aegyptensis (but also in Ottomania, Baluchimys, Hodsahibia, Lophibaluchia, Talahphiomys), upper molars of $P$. tunisiensis do not show the development of a central longitudinal crest (the mure; Fig. 2 ), which is generally short and links the metaconule (or the mesial extremity of the anterior arm of the hypocone) with the protoloph (i.e., complete mure) in more advanced species such as Acritophiomys, Phiomys, Metaphiomys, Turkanamys or even Bugtimys. In the absence of this character, the hypoflexus remains open buccally. A rough stage of this longitudinal crest (incipient, very short mure) can be however observed in some upper molars of $P$. algeriensis and $P$. aegyptensis, but never in $P$. tunisiensis. In contrast, in " $P$." durattalahensis, the mure is often complete, incomplete or absent on upper molars (Fig. 6A).

Concerning the lower teeth, $P$. tunisiensis differs from the other species of the genus in having the cristids less developed (i.e., weakly elevated), and in having more defined and bulbous cuspids. The hypoconid is not mesiodistally compressed and has neither a mesial outgrowth nor an ectostylid, three characters that can be observed in lower molars of $P$. aegyptensis and "P." durattalahensis (Figs 5D and 6B). On lower molars of P. tunisiensis, the posterolophid is trenchant in its buccal part and then weakens progressively in its lingual part. This cristid ends at the distal base of the entoconid (without connection), and as such the metaflexid remains open lingually. Lower molars of the other species exhibit a lingual wall made by the strong and high posterolophid (connected to the entoconid) and a strong, long and high posterior arm of the metaconid (including sometimes a mesostylid). This lingual wall is particularly elevated and continuous (including the entoconid) in $P$. algeriensis and in " $P$." durattalahensis (Figs 5D and 6B), while it can be interrupted (narrow notch, directly mesial to the entoconid) in P. aegyptensis (Fig. 5F). Despite the presence of a notch in some case, the lingual wall closes the talonid basin and the metaflexid lingually in $P$. algeriensis, $P$. aegyptensis and "P." durattalahensis. A continuous and elevated lingual wall is also observed in Waslamys (Fig. 6D). In P. tunisiensis, there is no elevated lingual wall; the posterior arm of the metaconid is present but moderately long and low, there is no defined mesostylid, and the talonid basin remains open lingually.

Mesially, lower molars of $P$. tunisiensis display a short (limited buccally) but distinct anterior cingulid (Figs 3B-D and 5B). This cingulid is not observed in the other species of Protophiomys, nor in Waslamys, Gaudeamus, or the earliest known caviomorphs (Canaanimys and Cachiyacui). In contrast, this character is widespread and often well-developed among early hystricognaths such as the African Acritophiomys, Talahphiomys, Phiomys, Metaphiomys, but also in the Asian Ottomania, Confiniummys, Baluchimys, Hodsahibia, Bugtimys, and Lophibaluchia. The absence of this character in $P$. algeriensis, $P$. aegyptensis and " $P$." durattalahensis is likely a derived condition, a loss which also occurred in Waslamys, Gaudeamus and the earliest caviomorphs.

Finally, P. tunisiensis differs also from the other species of the genus, notably in some morphological details of the permanent and deciduous premolars. As in the other species, the dp4 of $P$. tunisiensis displays a long and complete longitudinal ectolophid, but does not bear any trace of a mesoconid or a short mesolophid as can be observed on $\mathrm{dp} 4 \mathrm{~s}$ of $P$. algeriensis and $P$. aegyptensis (Fig. 5D, F). This lower deciduous premolar (KEB-1-006; Fig. 3E) displays also a slender and incomplete (interrupted buccally) hypolophid, while this cristid is generally strong and complete in dp4s of the other species. There is also neither a metalophulid I nor a metalophulid II (no posterior arm of the protoconid), whereas in the other species, dp4s display either a complete or an incomplete metalophulid II, and a complex anterior cristid (composite of the metalophulid I and the anterolophid). In contrast, dp4 of $P$. tunisiensis bears a small anteroconid, a character which is not observed in the other species of the genus, but present in dp4 of Talahphiomys lavocati (Fig. 6F). The $\mathrm{p} 4 \mathrm{~s}$ of $P$. tunisiensis differ also from the $\mathrm{p} 4 \mathrm{~s}$ in the other species in the absence of metalophulid I, while this cristid is present and complete in P. algeriensis, " $P$." durattalahensis and also in Waslamys for which the $\mathrm{p} 4$ is known. In contrast, they display a complete metalophulid II, while this cristid is generally incomplete (short posterior arm of the protoconid) in the other species of the genus, as well as in Waslamys.

\section{DISCUSSION AND CONCLUSIONS}

This new rodent species from Tunisia that we refer to the genus Protophiomys is one of the most slender species of that genus. Protophiomys tunisiensis is roughly equivalent in size to "P." durattalahensis, and half the dental size of $P$. algeriensis and $P$. aegyptensis. Its dental pattern is characterized by well-defined and salient cusps and cuspids, and by low and thin transverse and longitudinal crests and cristids. Buccal margins of upper molars and lingual margins of lower molars do not exhibit the enamel walls as developed as those observed in the other species of the genus, as well as in Waslamys, a coeval Protophiomys-like genus (see discussion below about this genus). Upper molars of P. tunisiensis are tetralophodont and do not show any marked tendency toward pentalophodonty, an occlusal pattern which is in contrast particularly well-developed in " $P$." durattalahensis, and somewhat "incipient" in P. algeriensis and to a lesser extent in $P$. aegyptensis (presence in some upper molars of these two latter taxa of a short mesolophule). Upper molars of $P$. tunisiensis do not exhibit a strong neo-endoloph (except on M3) as observed in the other species of the genus, but they present a very low and thin enterocrest, a character which is particularly strong in $P$. algeriensis and P. aegyptensis. " $P$." durattalahensis does not show this character on its upper molars. In fact, " $P$." durattalahensis displays a dental pattern that appears to be evolutionarily more advanced and somewhat divergent from that characterizing $P$. algeriensis, $P$. aegyptensis and $P$. tunisiensis. In particular, this is shown in the overall aspect of the teeth, which are less brachydont with crests and cristids more elevated and thicker (robust), but also in the development of a fully achieved pentalophodont pattern of upper molars, the presence of a strong mure (complete or incomplete), and in the lack of enterocrest. By this suite of derived dental traits and the lack of some characters otherwise found only in Protophiomys, in our opinion the species " $P$." durattalahensis could be regarded as belonging to a genus close to, but distinct from Protophiomys. This hypothesis was recently suggested by cladistic assessments of the dental evidence. Indeed, recent phylogenetic analyses (e.g., Antoine et al., 2012; Sallam et al., 2012; Barbière \& Marivaux, in press) advocate the paraor polyphyly of the genus Protophiomys, in placing "P." durattalahensis clearly apart from the other species of the genus. In contrast, analyses performed by Coster et al. (2010, 2012b) rather suggest that the three species of Protophiomys (P. algeriensis, P. aegyptensis, and " $P$." durattalahensis) are closely related. Sallam et al. (2012: 297) have suggested that " $P$." durattalahensis would rather be "a form that is very similar to Waslamys from BQ-2, and possibly congeneric". 


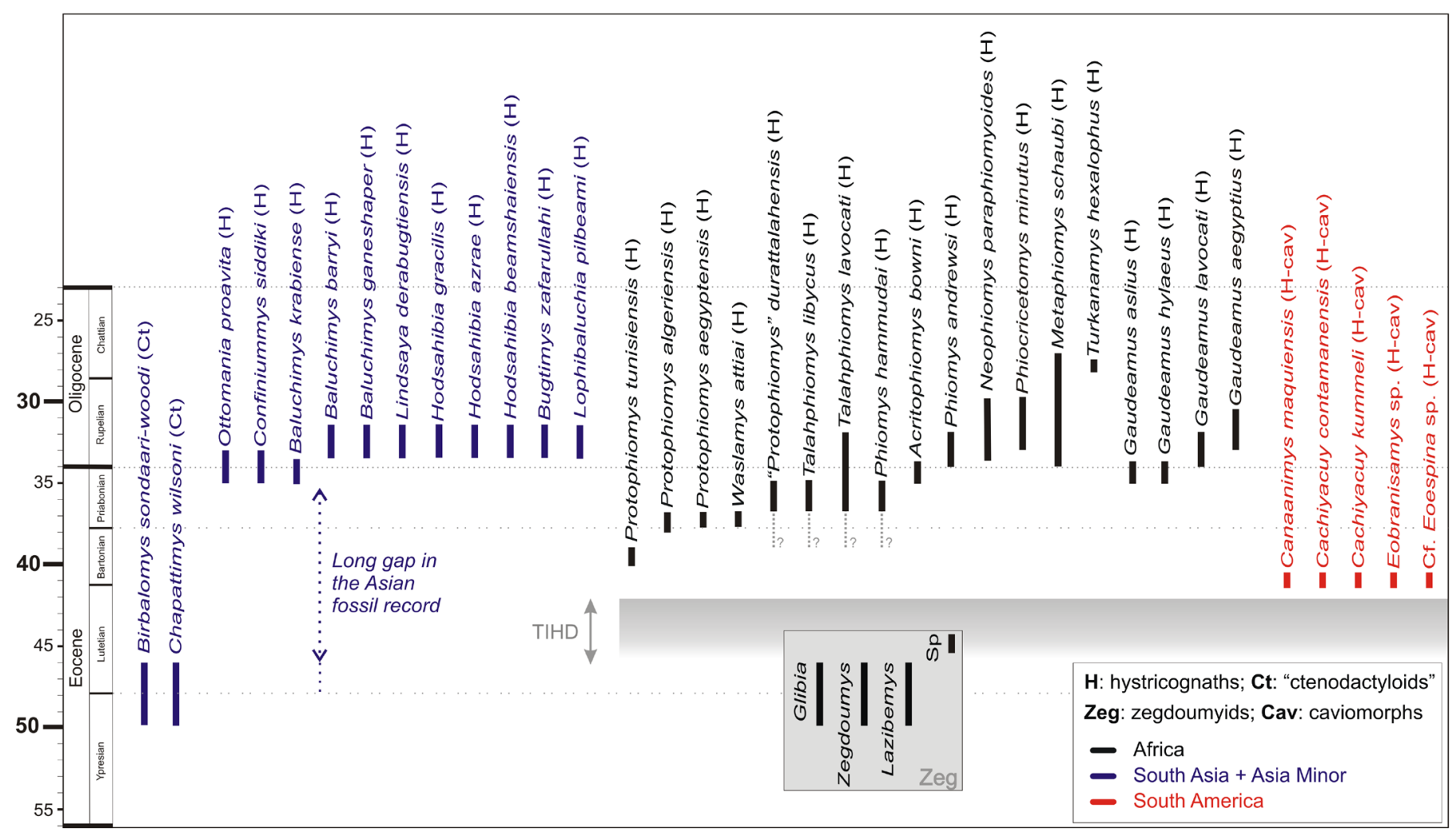

Figure 7. Temporal distribution of hystricognathous rodents during the Paleogene. Asian "ctenodactyloids" (Ct) are the sister group of the Hystricognathi clade. Zegdoumyid anomaluroids (Zeg) are the only rodents recorded in Africa during the early Paleogene (late early to early middle Eocene [Chambi, Gour Lazib, Aznag and BC-Sperrgebiet]). For South America, we have mentioned only the most ancient taxa known thus far. TIHD, time interval of hystricognath dispersals. Protophiomys tunisiensis nov. sp. from KEB-1 is the most ancient representative of hystricognaths in Africa, but it can be expected that hystricognaths were already present on that landmass given the caviomorph fossil evidence from the late middle Eocene of Peruvian Amazonia. In the context of an Asian origin for the Hystricognathi clade: the ancestral Asian hystricognaths likely colonized Africa sometime during the middle Eocene (TIHD, end of the Lutetian); hystricognaths were also able to continue at that time (during the TIHD) their pattern of intercontinental dispersal across the South Atlantic to invade South America. Africa might have played the role of a stopover for pioneer New World hystricognaths, "within a land-mass-hopping" process between Asia and South America (Antoine et al., 2012).

However, Waslamys lacks several diagnostic characters of "P." durattalahensis (e.g., presence of a complete mure, thick and tall crests and cristids, hypoflexus open lingually on M2 [no enterocrest]), but in turn exhibits anatomical details that are otherwise found only in Protophiomys (e.g., enterocrest, weak and variable development of the mesolophule). These differences are admittedly tenuous but in our opinion would rather suggest that Waslamys attiai is congeneric with Protophiomys. This hypothesis was recently advocated by Coster et al. (2012b), who proposed the subfamily Protophiomyinae (a clade including Protophiomys + "Waslamys"). In case Waslamys would be a junior synonym of Protophiomys, and given that " $P$." durattalahensis appears to us somewhat autapomorphic, this latter species from Dur At-Talah could then be the type and only species of a new genus. A revision of the species " $P$." durattalahensis is therefore required, but this study is beyond the scope of this paper. Regardless of the ongoing controversies over the alpha taxonomy of these early hystricognaths from Africa, the new rodent species from Tunisia we describe here is particularly critical for a better understanding of the morphological evolutionary tendencies observed in this rodent group. The dental specimens collected from KEB-1 display a suite of anatomical details that are primarily found in the different species of Protophiomys, but with a lesser degree of development compared with the other species included in the genus or in the close genera (i.e., Waslamys attiai and " $P$." durattalahensis). Such an apparent primitive evolutionary stage is corroborated by the greater antiquity of this Tunisian species ( 39.5 Ma, late middle Eocene) with respect to that of the Algerian and Egyptian species (i.e., earliest late Eocene; Seiffert, 2006, 2012).

Even if for a long time the record of earliest hystricognaths from the Old World was exclusive to Africa, over the past decades, hystricognaths ("baluchimyines") have been also recorded in the Paleogene of southern Asia (including the Indian Subcontinent and South-East Asia) and Asia Minor, notably from Thailand (Krabi, latest Eocene, Marivaux et al., 2000), Turkey (Süngülü, late Eocene/early Oligocene; de Bruijn et al., 2003), and from Pakistan (Bugti Hills, early Oligocene, Flynn et al., 1986; Marivaux et al., 2002; Marivaux \& Welcomme, 2003; Zinda Pir, early Oligocene, Flynn \& Cheema, 1994). These Asian fossil discoveries have demonstrated that this tropical province was also a major centre of an early hystricognathous rodent radiation during the Paleogene, and most likely the ancestral homeland of the Hystricognathi clade owing to the sister-group relationships with the Asian "ctenodactyloid" rodents (i.e., Ctenodactylidae, Tamquammyidae, Chapattimyidae, Yuomyidae, and Diatomyidae; Marivaux et al., 2002, 2004; Dawson et al., 2006; Sallam et al., 2009, 2012; see also Huchon et al., 2000, 2007 for the Ctenohystrica). However, the first representatives of the Hystricognathi clade in Asia date only from the end of the Eocene epoch (e.g., Baluchimys krabiense [Krabi, Thailand], Ottomania proavita 
[Süngülü, Turkey]; Table 2; Fig. 7). Given the phylogenetic relationships between Hystricognathi and Eocene Asian "ctenodactyloids", a much greater antiquity for the Hystricognathi clade might then be expected in Asia, an antiquity which might be traced back at least to the early middle Eocene (Antoine et al., 2012; Barbière \& Marivaux, in press). Such a great phylogenetically implied antiquity for hystricognaths points out the incompleteness of their Asian fossil record, a long temporal gap ( $>10$ Myr; Fig. 7) that must be better documented, in order to understand the origin and early adaptive radiation of that rodent group in Asia.

According to our current knowledge of the fossil record in Africa, hystricognaths are absent in significantly older, but reasonably well sampled, Eocene North African localities such as Chambi in western central Tunisia, or those from the Gour Lazib in the Sahara of western Algeria; localities dating from the late early to early middle Eocene (Hartenberger et al., 1997; Adaci et al., 2007; Coster et al., 2012a). These localities have yielded only zegdoumyid anomaluroids, a group of rodents endemic to Africa that is not closely related to the clade Hystricognathi (Vianey-Liaud et al., 1994; Marivaux et al., 2004, 2011; Marivaux, unpublished new data). Another mammal-bearing locality from North Africa, Aznag, Morocco, dating from the middle middle Eocene (middle Lutetian), has yielded one isolated rodent incisor (Tabuce et al., 2005). The material is meagre but the study of the enamel microstructure of this tooth has revealed a Schmelzmuster transitional from the pauciserial to the uniserial condition, a primitive type of enamel which is typical to that found in zegdoumyids from Algeria and Tunisia (e.g., Martin, 1993; Marivaux et al., 2011). A few teeth, tentatively referred to Protophiomys (P. cf. algeriensis), are reported from Sperrgebiet (Silica North and Silica South) in Namibia, two localities which are considered as dating from the middle middle Eocene (middle Lutetian; Pickford et al., 2008). However, there is an uncertainty regarding the Eocene age of these localities (see Coster et al., 2012a; Marivaux et al., 2012) since "Protophiomys" from Silica North is found in association with taxa that show closer affinities to Miocene rodents: a diamantomyid (Prepomonomys bogenfelsi), a thryonomyid (Apodecter cf. stromeri), a myophiomyid (Silicamys cingulatus), and a bathyergid (cf. Bathyergoides sp.). Furthermore, the robustness of the crests and cristids, and the moderate brachydonty observed in the few teeth referred to Protophiomys from Sperrgebiet do not match the conditions found in the different Eocene species of that genus. For this reason and because of the abundance of associated rodent species that are clearly of Miocene affinities, the presence of Protophiomys in Sperrgebiet, and the middle Eocene age of the Silica rodent-bearing localities are questionable. These Silica localities are most likely Miocene in age, and as such the alleged "Protophiomys"-like teeth are certainly referable to another genus. In contrast, the Black Crow locality from Sperrgebiet (close to the Silica localities; Pickford et al., 2008) displays a diverse assemblage including macro- and micromammals, which are undoubtedly of Eocene affinity. This locality has notably yielded a zegdoumyid rodent (Glibia namibiensis [Zegdoumys namibiensis sensu Marivaux et al., 2011]), but so far no hystricognaths. Although the Paleogene fossil record of North and Sub-Saharan Africa is far from being well-documented, there is currently no evidence of hystricognaths on that landmass during the early Paleogene. Given the age of the KEB-1 locality from Tunisia ( $239.5 \mathrm{Ma}$, late middle Eocene), Protophiomys tunisiensis nov. sp. is therefore the most ancient representative of hystricognathous rodents in Africa that is known thus far. The same is true for the primate recorded at KEB-1 (i.e., Amamria tunisiensis), which represents the most ancient occurrence of anthropoids in Africa (Marivaux et al., 2014).

In the context of an Asian origin for both hystricognath rodents (see aforementioned references on that subject) and anthropoid primates (e.g., Beard et al., 1994, 1996, 2009; Chaimanee et al., 1997, 2012, 2013; Jaeger et al., 1999, 2010b; Takai et al., 2001; Beard \& Wang, 2004; Jaeger \& Marivaux, 2005; Marivaux et al., 2005a; Kay, 2012; Seiffert, 2012), and given their apparent absence in early to middle middle Eocene localities of North Africa (e.g., Tabuce et al., 2005, 2009; Marivaux et al., 2011, 2013), these groups would then have dispersed from Asia to Africa sometime during the middle Eocene (Fig. 7). But when exactly these dispersals occurred remains unclear. Indeed, the temporal gap ( $\sim 5 \mathrm{Myr})$, spanning from the early middle Eocene (i.e., after Chambi, Glib Zegdou, Gour Lazib) to the late middle Eocene (i.e., before Kébar) in the African mammal fossil record, prevents any clear understanding of the nature and timing of middle Eocene immigrations of Asian terrestrial mammals into Africa (Fig. 7). Regarding hystricognathous rodents and particularly the close relationships between Old and New World hystricognaths, it is worth noting that these Asian stem hystricognaths that colonized Africa were in fact able to continue their pattern of intercontinental dispersal across the South Atlantic to invade South America as well. This scenario relies notably on the recent discovery of stem caviomorph rodents in $\sim 41 \mathrm{Myr}$ deposits from Peruvian Amazonia (Antoine et al., 2012). These early caviomorphs exhibit a dental pattern strikingly reminiscent (but somewhat autapomorphic and advanced in some dental traits) of that of their Paleogene African counterparts, a statement which suggests that this Amazonian locality "probably documents the earliest stages of caviomorph evolution" (Antoine et al., 2012: 1321). In a notable implication, this discovery indicates also that the dispersal of stem hystricognaths to South America from Africa must have occurred sometime during the middle Eocene, and a fortiori that hystricognaths must have been present in Africa at least just before $41 \mathrm{Myr}$. Interestingly, the middle Eocene was marked by a global warming recorded at the beginning of the Bartonian ("Mid Eocene Climatic Optimum" - MECO; Zachos et al., 2008; Bohaty et al., 2009; Vandenberghe et al., 2012). In this climatic context, the question arises as to whether these changes in the global paleoenvironmental conditions at that time have played a significant role in the dispersals of this rodent group but also other mammal groups from Asia to Africa, and then to South America (Marivaux et al., 2000, 2005b, 2011, 2014; Tabuce \& Marivaux, 2005; Sallam et al., 2009, 2010a-b; Antoine et al., 2012; Chaimanee et al., 2012; Barbière \& Marivaux, in press). In all cases, the much warmer and wetter conditions recorded at that time have certainly factored into the initial and successful adaptive radiations of hystricognaths in both Gondwanian landmasses.

In sum, if Protophiomys tunisiensis nov. sp. is so far the most ancient representative of hystricognaths in Africa, it can however be expected that this rodent group was already present on that landmass given the new caviomorph fossil evidence. The arrival of hystricognaths in Africa from South Asia certainly predates the depositional period of the Kébar sediments (KEB-1), but perhaps not by much time (Fig. 7). $P$. tunisiensis was perhaps morphologically not so far from the pioneer hystricognath that colonized Africa from South Asia. Only continuing field efforts in Lutetian deposits of Africa, South Asia but also South America will allow for substantial 
discoveries of early hystricognathous rodents. These new data should provide us a more accurate temporal framework of the hystricognath dispersal events, but also further our understanding of the mode and pathways of these dispersals, as well as the macroevolutionary and phylogenetic patterns of their initial radiations.

\section{ACKNOWLEDGEMENTS}

The authors are very grateful to Suzanne Jiquel, Anne-Lise Charruault, Anusha Ramdarshan, and Anthony Ravel (ISE-M, Montpellier), and Faouzi M'Nasri (ONM, Tunis) for their assistance during the field seasons in the Kassérine and Sidi-Bouzid regions in Tunisia. We are indebted to the inhabitants of the Amamria hamlet (near Soug-Jedid village; Sidi Bouzid Township) for their hospitality and technical help during the fieldwork. We are embedded to Mustapha Ben Haj Ali, the former head of the "Service Géologique de l'ONM" (Tunis) for his enthusiasm regarding our collaborative project in Tunisia. We thank Etienne Steurbaut (Royal Belgian Institute of Natural Sciences, Leuven) for his examination of the sediment of the KEB-1 locality in search of nannoplancton. Many thank to Johan Yans (University of Namur, NaGRIDD, Namur) for the K-Ar dating performed on glauconite grains from the glauconitic clays of the KEB-1 locality. Finally, we warmly thank Chantal Cazevieille (Centre de Ressources en Imagerie Cellulaire, Montpellier) for access to a scanning electron microscope facility. Pauline Coster (Biodiversity Institute, University of Kansas) and Erik R. Seiffert (Stony Brook University) provided formal reviews of this manuscript that significantly enhanced the final version. This research was supported by the French ANR-ERC PALASIAFRICA Program (ANR-08-JCJC-0017), a grant from the "Conseil Scientifique" (CS) of the "Université Montpellier 2" (UM2), and by the ONM of Tunis (AC-1785). This is ISE-M publication 2014-059.

\section{BIBLIOGRAPHY}

Adaci, M., Tabuce, R., Mahboubi, M., Bensalah, M., Fabre, P.-H., Hautier, L., Marivaux, L., Mebrouk, F., Lazzari, V., Otéro, O., Peigné, S., Tong, H., Jaeger, J.-J., 2007. Nouveaux sites à vertébrés paléogènes dans la région des Gour Lazib et Glib Zegdou (Sahara Nord-occidental, Algérie). Comptes Rendus Palevol 6, 535-544

Antoine, P. O., Marivaux, L., Croft, D. A., Billet, G., Ganerød, M., Jaramillo, C., Martin, T., Orliac, M. J., Tejada, J., Altamirano, A. J., Duranthon, F., Fanjat, G., Rousse, S., Salas-Gismondi, R., 2012. Middle Eocene rodents from Peruvian Amazonia reveal the pattern and timing of caviomorph origins and biogeography. Proceedings of the Royal Society of London, B 279, 1319-1326.

Barbière, F., Marivaux, L., in press. Phylogeny and evolutionary history of hystricognathous rodents from the Old World during the Tertiary: new insights into the emergence of modern "phiomorph" families. In: Cox, F. G., Hautier, L. (Eds.), Evolution of the Rodents: Advances in Phylogenetics, Functional Morphology and Development. Cambridge University Press, Cambridge.

Beard, K. C., Qi, T., Dawson, M. R., Wang, B., Li, C., 1994. A diverse new primate fauna from middle Eocene fissure-fillings in southeastern China. Nature 368, 604-609.

Beard, K. C., Tong, Y., Dawson, M. R., Wang, J., Huang, X., 1996. Earliest complete dentition of an anthropoid primate from the late middle Eocene of Shanxi Province, China. Science 272, $82-85$.

Beard, K. C., Wang, J., 2004. The eosimiid primates (Anthropoidea) of the Heti Formation, Yuanqu Basin, Shanxi and Henan Provinces, People's Republic of China. Journal of Human Evolution 46, 401-432.

Beard, K. C., Marivaux, L., Chaimanee, Y., Jaeger, J.-J., Marandat, B., Tafforeau, P., Soe, A. N., Tun, S. T., Kyaw, A. A., 2009. A new primate from the Eocene Pondaung Formation of Myanmar and the monophyly of Burmese amphipithecids. Proceedings of the Royal Society of London, B 276, 3285-3294.

Bohaty, S. M., Zachos, J. C., Florondo, F., Delaney, M. L., 2009. Coupled greenhouse warming and deep-sea acidification in the middle Eocene. Paleoceanography 24, PA2207.

Chaimanee, Y., Suteethorn, V., Jaeger, J.-J., Ducrocq, S., 1997. A new late Eocene anthropoid primate from Thailand. Nature 385, 429-431.

Chaimanee, Y., Chavasseau, O., Beard, K. C., Kyaw, A. A., Soe, A. N., Sein, C., Lazzari, V., Marivaux, L., Marandat, B., Swe, M., Rugbumrung, M., Lwin, T., Valentin, X., Thein, Z. M. M., Jaeger, J.-J., 2012. A new middle Eocene primate from Myanmar and the initial anthropoid colonization of Africa. Proceedings of the National Academy of Sciences, USA 109, 10293-10297.

Chaimanee, Y., Chavasseau, O., Lazzari, V., Euriat, A., Jaeger, J.-J., 2013. A new Late Eocene primate from the Krabi Basin (Thailand) and the diversity of Palaeogene anthropoids in southeast Asia. Proceedings of the Royal Society of London, B 280, 1471-2954.

Coster, P., Benammi, M., Lazzari, V., Billet, G., Martin, T., Salem, M., Bilal, A. A., Chaimanee, Y., Schuster, M., Valentin, X., Brunet, M., Jaeger, J.-J., 2010. Gaudeamus lavocati sp. nov. (Rodentia, Hystricognathi) from the early Oligocene of Zallah, Libya: first African caviomorph? Naturwissenschaften 97, 697-706.

Coster, P., Benammi, M., Mahboubi, M., Tabuce, R., Adaci, M., Marivaux, L., Bensalah, M., Mahboubi, S., Mahboubi, A., Maameri, C., Jaeger, J.-J., 2012a. Chronology of the early-middle continental Eocene deposits of Africa: magnetic stratigraphy and biostratigraphy of the El Kohol and Glib Zegdou formations, Algeria. Geological Society of America Bulletin 124, 1590-1606.

Coster, P., Benammi, M., Salem, M., Bilal, A. A., Chaimanee, Y., Valentin, X., Brunet, M., Jaeger, J.-J., 2012b. New hystricognath rodents from the lower Oligocene of Central Libya (Zallah Oasis, Sahara desert): systematic, phylogeny and biochronologic implications. Annals of Carnegie Museum 80, 239-259.

Dawson, M. R., Marivaux, L., Li, C.-K., Beard, K. C., Métais, G., 2006. Laonastes and the "lazarus effect" in Recent mammals. Science 311, 1456-1458.

de Bruijn, H., Ünay, E., Saraç, G., Yïlmaz, A., 2003. A rodent assemblage from the Eo/Oligocene boundary interval near Süngülü, Lesser Caucasus, Turkey. In: López-Martínez, N., Peláez-Campomanes, P., Henández Fernández, M. (Eds.), Coloquios de Paleontologia. En honor al Dr. Remmert Daams. Surrounding fossil mammals: dating, evolution and paleoenvirontment. Facultad de Ciencias Geologicas Departamento de Paleontologia, Madrid, pp. 47-76.

Fejfar, O., 1987. Oligocene rodents from Zallah Oasis, Libya. Münchner Geowiss Abhandlungen A 10, 265-268.

Flynn, L. J., Jacobs, L. L., Cheema, I. U., 1986. Baluchimyinae, a new ctenodactyloid rodent subfamily from the Miocene of Baluchistan. American Museum Novitates 2841, 1-58.

Flynn, L. J., Cheema, I. U., 1994. Baluchimyine Rodents from the Zinda Pir Dome, Western Pakistan : systematic and biochronologic implications. In: Tomida, Y., Li, C., Setoguchi, T. (Eds.), Rodents and Lagomorph Families of Asian Origins and Diversification. National Science Museum Monographs, Tokyo, Kyoto, pp. 115-129.

Hartenberger, J. L., Crochet, J.-Y., Martinez, C., Feist, M., Godinot, M., Mannai Tayech, B., Marandat, B., Sigé, B., 1997. Le gisement de mammifères de Chambi (Eocène, Tunisie centrale) dans son contexte géologique. Apport à la connaissance de l'évolution des mammifères en Afrique. In: Aguilar, J.-P., Legendre, S. Michaux, J. (Eds.), Actes du Congrès BiochroM'97. Mémoires des Travaux de l'E.P.H.E., Montpellier, pp. 263-274. 
Huchon, D., Catzeflis, F. M., Douzery, E. J.-P., 2000. Variance of molecular datings, evolution of rodents, and the phylogenetic affinities between Ctenodactylidae and Hystricognathi. Proceedings of the Royal Society of London, B 267, 393-402.

Huchon, D., Chevret, P., Jordan, U., Kilpatrick, C. W., Ranwez, V., Jenkins, P. D., Brosius, J., Schmitz, J., 2007. Multiple molecular evidences for a living mammalian fossil. Proceedings of the National Academy of Sciences, USA 104, 7495-7499.

Hussain, S. T., De Bruijn, H., Leinders, J. M., 1978. Middle Eocene Rodents from the Kala Chitta Range (Punjab, Pakistan). Palaeontology 81, 101-112.

International Commission on Zoological Nomenclature (ICZN), 1999. International code of zoological nomenclature (4th ed.). The International Trust for Zoological Nomenclature, London.

Jaeger, J.-J., Denys, C., Coiffait, B., 1985. New Phiomorpha and Anomaluridae from the late Eocene of North-West Africa: phylogenetic implications. In: Luckett, W. P., Hartenberger, J.-L. (Eds.), Evolutionary Relationships among Rodents, A Multidisciplinary Analysis. Plenum Press, New York, London, pp. 567-588.

Jaeger, J.-J., Thein, T., Benammi, M., Chaimanee, Y., Soe, A. N., Lwin, T., Wai, S., Ducrocq, S., 1999. A new primate from the middle Eocene of Myanmar and the Asian early origin of anthropoids. Science 286, 528-530.

Jaeger, J.-J., Marivaux, L., 2005. Shaking the earliest branches of anthropoid primate evolution. Science 310, 244-245.

Jaeger, J.-J., Marivaux, L., Salem, M., Bilal, A. A., Chaimanee, Y., Marandat, B., Valentin, X., Duringer, P., Schuster, M., Benammi, M., Métais, E., Brunet, M., 2010a. New rodent assemblages from the Eocene Dur at-Talah escarpment (Sahara of Central Libya): systematic, biochronologic and paleobiogeographic implications. Zoological Journal of the Linnean Society 160, 195-213.

Jaeger, J.-J., Beard, K. C., Chaimanee, Y., Salem, M., Benammi, M., Hlal, O. A., Coster, P., Bilal, A. A., Duringer, P., Schuster, M., Valentin, X., Marandat, B., Marivaux, L., Métais, E., Hammuda, O., Brunet, M., 2010b. Late middle Eocene epoch of Libya yields earliest known radiation of African anthropoids. Nature 467, 1095-1098.

Kay, R. F., 2012. Evidence for an Asian origin of stem anthropoids. Proceedings of the National Academy of Sciences, USA 109, 10132-10133.

Korvenkontio, V. A., 1934. Mikroskopische Untersuchungen an Nagerincisiven unter Hinweis auf die Schmelzstruktur der Backenzähne. Annales Zoologici Societatis Zoologici Botanicae Fennicae Vanamo 2, 1-274.

Marivaux, L., Benammi, M., Ducrocq, S., Jaeger, J.-J., Chaimanee, Y., 2000. A new baluchimyine rodent from the Late Eocene of the Krabi Basin (Thailand): paleobiogeographic and biochronologic implications. Comptes rendus de l'Académie des Sciences 331, 427-433.

Marivaux, L., Welcomme, J.-L., Vianey-Liaud, M., Jaeger, J.-J., 2002. The role of Asia in the origin and diversification of hystricognathous rodents. Zoologica Scripta 31, 225-239.

Marivaux, L., Welcomme, J.-L., 2003. Diatomyid and baluchimyine rodents from the Oligocene of Pakistan (Bugti Hills, Balochistan): systematic and paleobiogeographic implications. Journal of Vertebrate Paleontology 23, 420-434.

Marivaux, L., Vianey-Liaud, M., Jaeger, J.-J., 2004. High-level phylogeny of early Tertiary rodents: dental evidence. Zoological Journal of the Linnean Society 142, 105-132.

Marivaux, L., Antoine, P.-O., Baqri, S. R. H., Benammi, M., Chaimanee, Y., Crochet, J.-Y., De Franceschi, D., Iqbal, N., Jaeger, J.-J., Métais, G., Roohi, G., Welcomme, J.-L., 2005a. Anthropoid primates from the Oligocene of Pakistan (Bugti Hills): data on early anthropoid evolution and biogeography. Proceedings of the National Academy of Sciences, USA 102, 8436-8441.

Marivaux, L., Ducrocq, S., Jaeger, J.-J., Marandat, B., Sudre, J., Chaimanee, Y., Tun, S. T., Htoon, W., Soe, A. N., 2005b. New remains of Pondaungimys anomaluropsis (Rodentia, Anom- aluroidea) from the latest middle Eocene Pondaung Formation of Central Myanmar. Journal of Vertebrate Paleontology 25, 214-227.

Marivaux, L., Adaci, M., Bensalah, M., Gomes Rodrigues, H., Hautier, L., Mahboubi, M., Mebrouk, F., Tabuce, R., Vianey-Liaud, M., 2011. Zegdoumyidae (Rodentia, Mammalia), stem anomaluroid rodents from the early to middle Eocene of Algeria (Gour Lazib, Western Sahara): new dental evidence. Journal of Systematic Palaeontology 9, 563-588.

Marivaux, L., Lihoreau, F., Manthi, K. F., Ducrocq, R., 2012. A new basal phiomorph (Rodentia, Hystricognathi) from the Late Oligocene of Lokone (Turkana Basin, Kenya). Journal of Vertebrate Paleontology 32, 646-657.

Marivaux, L., Ramdarshan, A., Essid, E. M., Marzougui, W., Khayati Ammar, H., Lebrun, R., Marandat, B., Merzeraud, G., Tabuce, R., Vianey-Liaud, M., 2013. Djebelemur, a tiny pre-toothcombed primate from the Eocene of Tunisia: a glimpse into the origin of crown strepsirhines. PLoS ONE 8, e80778.

Marivaux, L., Essid, E. M., Marzougui, W., Khayati Ammar, H., Adnet, S., Marandat, B., Merzeraud, G., Ramdarshan, A., Tabuce, R., Vianey-Liaud, M., Yans, Y., 2014. A morphological intermediate between eosimiiform and simiiform primates from the late middle Eocene of Tunisia: macroevolutionary and paleobiogeographic implications of early anthropoids. American Journal of Physical Anthropology 154, 387-401.

Martin, T., 1994. African origin of caviomorph rodents is indicated by incisor enamel microstructure. Paleobiology 20, 5-13.

Merzeraud, G., Essid, E. M., Khayati Ammar, H., Marzougui, W., Adnet, S., Marivaux, L., Tabuce, R., Vianey-Liaud, M. Des dépôts marins depuis la fin de l'Eocène moyen sur la bordure orientale de l'île de Kassérine : sédimentologie de faciès et stratigraphie séquentielle de la série sédimentaire du Djebel el Kébar (Tunisie centrale). Bulletin de la société géologique de France, in review.

Osborn, H. F., 1908. New fossil mammals from the Fayûm Oligocene, Egypt. American Museum of Natural History Bulletin 26, 415-424.

Pickford, M., Senut, B., Morales, J., Mein, P., Sanchez, I. M., 2008. Mammalia from the Lutetian of Namibia. Memoirs of the Geological Survey of Namibia 20, 465-514.

Sallam, H. M., Seiffert, E. R., Steiper, M. E., Simons, E. L., 2009. Fossil and molecular evidence constrain scenarios for the early evolutionary and biogeographic history of hystricognathous rodents. Proceedings of the National Academy of Sciences, USA 106, 16722-16727.

Sallam, H. M., Seiffert, E. R., Simons, E. L., 2010a. A highly derived anomalurid rodent from the earliest late Eocene of Egypt. Palaeontology 53, 803-813.

Sallam, H. M., Seiffert, E. R., Simons, E. L., Brindley, C., 2010b. A large-bodied anomaluroid rodent from the earliest late Eocene of Egypt: phylogenetic and biogeographic implications. Journal of Vertebrate Paleontology 30, 1579-1593.

Sallam, H. M., Seiffert, E. R., Simons, E. L., 2011. Craniodental morphology and systematics of a new family of hystricognathous rodents (Gaudeamuridae) from the Late Eocene and Early Oligocene of Egypt. PLoS ONE 6, 1-29.

Sallam, H. M., Seiffert, E. R., Simons, E. L., 2012. A basal phiomorph (Rodentia, Hystricognathi) from the late Eocene of the Fayum Depression, Egypt. Swiss Journal of Palaeontology 131, 283-301.

Seiffert, E. R., 2006. Revised age estimates for the later Paleogene mammal faunas of Egypt and Oman. Proceedings of the National Academy of Sciences, USA 103, 5000-5005.

Seiffert, E. R., 2012. Early primate evolution in Afro-Arabia. Evolutionary Anthropology 21, 239-253.

Tabuce, R., Marivaux, L., 2005. Mammalian interchanges between Africa and Eurasia: an analysis of temporal constraints on plausible anthropoid dispersal during the Paleogene. Anthropological Science 113, 27-32.

Tabuce, R., Adnet, S., Cappetta, H., Noubhani, A., Quillevéré, F., 2005. Aznag (bassin d'Ouarzazate, Maroc), nouvelle localité 
à sélaciens et mammifères de l'Eocène moyen (Lutétien) d'Afrique. Bulletin de la société géologique de France 176, 381-400.

Tabuce, R., Marivaux, L., Lebrun, R., Adaci, M., Bensalah, M., Fabre, P.-H., Fara, E., Gomes Rodrigues, H., Hautier, L., Jaeger, J.-J., Lazzari, V., Mebrouk, F., Peigné, S., Sudre, J., Tafforeau, P., Valentin, X., Mahboubi, M., 2009. Anthropoid vs. strepsirhine status of the African Eocene primates Algeripithecus and Azibius: craniodental evidence. Proceedings of the Royal Society of London, B 276, 4087-4094.

Takai, M., Shigehara, N., Aung, A. K., Tun, S. T., Soe, A. N., Tsubamoto, T., Thein, T., 2001. A new anthropoid from the latest middle Eocene of Pondaung, Central Myanmar. Journal of Human Evolution 40, 393-409.

Vandenberghe, N., Hilgen, F. J., Speijer, R. P., 2012. Chapter 28: The Paleogene period. In: Gradstein, F. M., Ogg, J. G., Schmitz, M., Ogg, G. (Eds.), The Geological Time Scale 2012. Elsevier Science Ltd, Oxford, pp. 855-921.
Vianey-Liaud, M., Jaeger, J.-J., Hartenberger, J.-L., Mahboubi, M., 1994. Les rongeurs de l'Eocène d'Afrique Nord-Occidentale (Glib Zegdou (Algérie) et Chambi (Tunisie)) et l'origine des Anomaluridae. Palaeovertebrata 23, 93-118.

Wood, A. E., 1968. Part II: The African Oligocene Rodentia. In: Remington, J. E. (Ed.), Early Cenozoic Mammalian Faunas Fayum Province, Egypt. Peabody Museum of Natural History Yale University, New Haven, pp. 23-105.

Wood, A. E., Wilson, R. W., 1936. A suggested nomenclature for the cusps of the cheek teeth of Rodents. Journal of Paleontology $10,388-391$.

Zachos, J. C., Dickens, G. R., Zeebe, R. E., 2008. An early Cenozoic perspective on greenhouse warming and carbon-cycle dynamics. Nature 451, 279-283. 